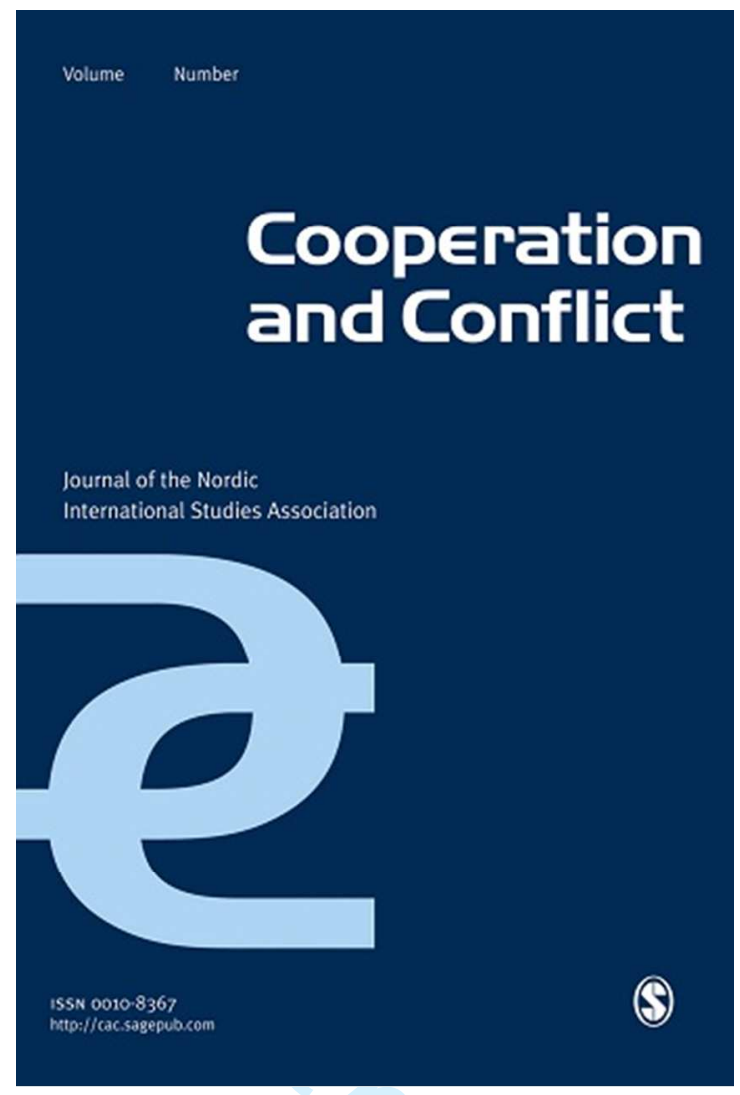

\title{
Operationalizing the decentring agenda: Analysing European foreign policy in a non-European and post- Western World
}

\begin{tabular}{|r|l|}
\hline Journal: & Cooperation and Conflict \\
\hline Manuscript ID & CAC-17-0073.R1 \\
\hline Manuscript Type: & Original Article \\
\hline Keywords: & $\begin{array}{l}\text { Decentring, Eurocentrism, European foreign policy, European Union, } \\
\text { Foreign policy, Provincializing }\end{array}$ \\
\hline & $\begin{array}{l}\text { Eurocentrism in the analysis of European foreign policy often renders } \\
\text { scholars blind to other world views and realties, although engaging with } \\
\text { these may be critical for understanding the relevance and impact of this } \\
\text { policy in other parts of the world. Notwithstanding calls for decentring the } \\
\text { study of International Relations and European foreign policy in particular, } \\
\text { scholars of European foreign policy generally lack the tools and conceptual } \\
\text { lenses to overcome Eurocentrism in their analyses. This article proposes an } \\
\text { analytical framework to systematically open up for difference, and to see } \\
\text { and understand dynamics and realities that go beyond dominant } \\
\text { Eurocentric accounts, while trying to avoid the pitfalls of simplification and }\end{array}$ \\
\hline
\end{tabular}


knowledge fragmentation. The framework consists of six partially overlapping decentring categories - spatial, temporal, normative, polity, linguistic, and disciplinary decentring - and is developed through two dimensions of the Decentring Agenda proposed by Fisher Onar and Nicolaïdis (2013): 'provincializing' (questioning Eurocentric perspectives) and 'engagement' (learning from others' perspectives). In this way, this article aims to support scholars of European foreign policy in overcoming Eurocentrism and in operationalizing the Decentring Agenda.

\section{SCHOLARONE \\ Manuscripts}




\section{Introduction}

In The Decentring Agenda: Europe as a post-colonial power, Fisher Onar and Nicolaïdis (2013: 283) call for 'a paradigm shift that decentres the study and practice of Europe's international relations ... necessary both to make sense of our multipolar order and to reconstitute European agency in a non-European world' ${ }^{1}$. Their plea fits within a broader academic debate about the need to overcome Eurocentrism and to decentre Europe, the West and the International Relations (IR) discipline (Chakrabarty, 2000; Jørgensen, 2010; Morozov, 2013; Nayak and Selbin, 2010), to open up for 'difference' (Inayatullah and Blaney, 2004; Tickner and Blaney, 2012), and to explore non-western IR theories and approaches (Bischoff et al., 2016; Buzan and Acharya, 2010; Tickner and Wæver, 2009).

In the literature on Europe's international relations, some strands go beyond Eurocentric accounts, such as the external perceptions literature (Chaban and Holland, 2013; Ejdus and Juncos, forthcoming; Lucarelli and Fioramonti, 2010; Mayer and Zielonka, 2012), assessments of the Normative Power Europe (NPE) concept that point to its Eurocentric discourse (Diez, 2013; Sjursen, 2006; Staeger, 2016), and specific publications on the policy of the European Union (EU) towards the Arab world (Börzel et al., 2015; Cavatorta and Pace, 2010) or China (Chen, 2016; Pan, 2012). Nevertheless, these are exceptions. As the analysis of 450 articles in seven key academic journals indicates, Eurocentrism remains predominant in the analysis of European foreign policy (Keuleers et al., 2016). This increasingly raises questions about the

\footnotetext{
${ }^{1}$ For the difference and relationship between the terms 'Europe' and 'the West' and 'Eurocentrism' and 'westerncentrism', see Fisher Onar and Nicolaïdis (2013, p. 284). We mainly refer to 'Europe(an)' and 'Eurocentrism', acknowledging that these are largely embedded within the broader 'western' context.
} 


\begin{abstract}
relevance of a scholarship on foreign policy that is rather inward-looking and from which the 'foreign' is largely missing.

However, a framework for the systematic analysis of what 'difference' may entail and what it may look like to go beyond a Eurocentric perspective has not yet been developed. The purpose of this paper is to provide an analytical toolbox which can support scholars of European foreign policy in overcoming Eurocentrism and opening up for difference in a systematic way by operationalizing the Decentring Agenda.
\end{abstract}

\title{
Operationalizing the Decentring Agenda: building blocks and challenges
}

Building on earlier ventures into analysing European foreign policy from the outside (Keukeleire, 2014; Keukeleire and Thépaut, 2012), we propose six partially overlapping and coconstitutive categories for decentring (Table 1). The first five categories deal with ontological questions: spatial decentring mainly refers to material context, while time, norms, polity and language tackle immaterial contextual factors. These categories - and further developed subcategories - allow us to systematically cover major facets of what 'difference' may entail and what it may look like to go beyond a Eurocentric perspective. A separate sixth category is disciplinary decentring, focusing on epistemological and methodological challenges.

For each of the categories, we focus on two analytical dimensions proposed by Fisher Onar and Nicolaïdis (2013) in their Decentring Agenda: provincializing and engagement. Provincializing means 'to unpack the social scientific categories, assumptions and paradigms that underpin Eurocentric truth claims' and to question 'Eurocentric accounts of world history and politics' as well as 'Eurocentric “civilizational” assumptions'. Engagement implies learning about and from 
others' perspectives and accounts of the world and engaging with the assumptions, worldviews and value systems that underpin them (Fisher Onar and Nicolaïdis, 2013: 286). In this article, we assess how both dimensions can be tackled in the analysis of European foreign policy (Table 1), in view of future research that can yield insights and policy recommendations for a 'reconstruction' or 'renewing of EU praxis in a non-European world, from the outside in' (Fisher Onar and Nicolaïdis, 2013: 286).

Table 1

Decentring is not without pitfalls and challenges. A first obvious challenge is that most western scholars are trained within western IR paradigms or the conventionally Eurocentric field of European Studies. How can they systematically engage in decentring, while being inherently part of a 'Eurocentric box', shaped by a western-centric intellectual and cultural legacy? There is a normal tendency to revert to known frames of reference or to filter out ideas which although important in non-European/western contexts - do not resonate with the analyst's own ontological, epistemological or linguistic framework, or are undetectable by conventional methodological approaches (Fisher Onar and Nicolaïdis, 2013: 285, 290). The subcategories in our framework aim to support scholars in overcoming this pitfall.

Secondly, a clear distinction should be made between the Decentring Agenda as an analytical or heuristic tool on the one hand, and as a normative judgement on the other. The aim is to assist scholars in detecting, labelling and understanding concepts, ideas and practices that do not fit within their usual frames of reference, without making a priori normative judgements. 
Third, one must prevent decentring from leading to simplifications and 'othering' or overemphasising or artificially creating difference between 'the West' and 'the Rest'. As Morozov (2013: xiii) emphasises, 'the border between the West and the non-West is not a geographical one - it runs across societies and shapes our national and social identities'. Areas and societies are characterised by a high degree of complexity and hybridity: several processes and realities can exist in parallel, can be overlapping or separated, compatible or incompatible, mutually reinforcing or undermining, visible or invisible, and dynamic in space and time. Decentring can help increase receptivity to this complexity, which exists not only outside but also within Europe and the West.

A fourth challenge is avoiding that decentring merely leads to case-specific knowledge, without relevance for other cases or the potential for comparative analysis or generalisation. The inherent limitations of the abstract level are then swapped for the constraints of ad-hoc knowledge. This calls for pursuing a middle level of categorisation. Following the approach of Chabal and Dalloz (2006: 22), the aim here is to develop a framework which can be applied 'to widely divergent cases, in different areas, and enabling the analyst to [assess both] singularities and commonalities' and translate 'local [...] accounts into a language that is amenable to comparison with other cases'.

This article aims to provide an applicable analytical framework for decentring by proposing conceptual lenses and categorizations that facilitate seeing and understanding dynamics and realities that are not easily captured with predominant assumptions, theories and methods, while trying to avoid simplifications and knowledge fragmentation. In this article, we mainly focus on the four immaterial decentring categories and on disciplinary decentring; however, as a 
preliminary analytical step, analysts should consider 'space' and 'spatial decentring' to form an idea of the material context of the region under examination.

\section{Spatial decentring}

As Therborn asserts, 'politics begins with place [and] the Western notion of politics derives from a particular place and the concerns of its inhabitants' (Therborn, 2006: 509). Spatial decentring therefore looks into the basic geographic and material features of a society, country or region - geographical location and size, topographical aspects, environment, natural resources, etc. - and the way 'space' is organised and perceived, both internally and in relationship to other 'spaces'. This includes infrastructure, availability of public goods and services, socio-economic features, demography, etc. (Al-Rodhan, 2009; Tickner, 2003).

Al-Rodhan's (2009) work on 'meta-geopolitics' provides a useful categorisation of features that determine how space is organised. As a systematic analysis of these features is beyond the scope of this article, we only point in general terms to what spatial provincializing can imply. It means acknowledging that European foreign policy analysts see the world from within a particular European/western geographic and spatial setting, involving assumptions about how the world is or should be organised. The European conceptualisation of space is characterised by the 'territorial trap' (see polity decentring; Agnew, 1994), as well as by some basic features of Europe's geographic and spatial context (Cole, 2013) which may not be taken for granted elsewhere.

Engagement requires that analysts learn about the various spatial and geographic features in other areas and about their impact, including their potential influence on the (in)effectiveness of 
European foreign policy. For example, when analysing the EU's policy towards Libya (including the EU's Integrated Border Assistance Mission) scholars should take into account the country's exceptional geographic features, consisting largely of desert and with a $4350 \mathrm{~km}$ border and $1770 \mathrm{~km}$ coastline. And are we fully aware that the EU's call for transparent and democratic elections in the DR Congo is directed to a country half the size of Europe itself, with limited transportation infrastructure, rather weak administration and a low level of literacy?

\section{Temporal decentring}

Temporal provincializing implies an awareness that in the analysis of European foreign policy, a Eurocentric framing of history is often generalised to other parts of the world or is taken as a point of departure for assessing Europe's relations with and policies towards other regions. Firstly, modern Europe's experiences are reflected in an 'orthodox set' of benchmark dates or foundational events that took place in Europe or the broader West (Chakrabarty, 2007: 7). Buzan and Lawson (2014) point to the opening of sea lanes from Europe to the Americas and Indian Ocean in 1500, the 1648 Treaty of Westphalia, WWI and WWII, the start and end of the Cold War, and '9/11'. These events are related to specific historical experiences, collective memories and lessons learnt, also regarding Europe's external relations and policies - e.g. the benchmark of opening the sea lanes reflects an imperialist, colonialist European perspective. The analysis of EU foreign policy also takes as major reference points foundational EU-related events, such as the start of European integration (partly responding to the world wars) or the Maastricht and Lisbon Treaty (creating the Common Foreign and Security Policy, and the 
European External Action Service and High Representative/Vice-President of the European Commission function, respectively).

Secondly, provincializing implies acknowledging the specificity of Europe's historical trajectory. Chakrabarty (2007) highlights that western social science is generally inscribed within a modernity paradigm in which evolution is thought of as fundamentally progressive and having a universal orientation. This specific idea of modernity is defined by Taylor (2002: 92) as 'new practices and institutional forms (science, technology, industrial production, urbanization) and new ways of living (individualism, secularization, instrumental rationality)'. It is seen as the basis for 'European political modernity' (Fischer Onar and Müftüler-Baç, 2011: 379), the result of idealised interpretations of humanism, the Enlightenment, the French Revolution and other European 'emancipatory' movements and ideologies (Pasture, 2015). This modernity paradigm has often been projected onto the histories of the non-West (Buzan and Little, 2000) and influences Europe's assumptions, expectations and judgements regarding developmental trajectories in other parts of the world. However, this idea of modernity was 'drawn from very particular intellectual and historical traditions that could not claim any universal validity' (Chakrabarty, 2007: xiii).

A related element of Eurocentrism is the assumption that Europe's current situation is selfevident and that we can look to modern Europe to make judgements about how other countries should behave and develop. As Fukuyama (2011: 14) notes, 'people living in industrialized countries now suffer from a historical amnesia regarding how their societies came to that point in the first place', disregarding the often long, painful and non-linear evolution and the complex historical circumstances under which this occurred, and the diversified reality to which it gave 
rise. Provincializing thus includes an awareness of evolution and diversity within Europe and the West itself and a willingness to go beyond idealised, mythicised or simplified versions of the own historical trajectories, including the myth of the EU's 'virgin birth', detached from the colonial past of its member states (Nicolaïdis, 2015; Pasture, 2015).

Finally, provincializing entails a consciousness about the particular European perception of time and how this impacts on the analysis of its external relations. As Birth (2016) emphasises, our understanding of temporal diversity is constrained by the logic of European-derived ideas about time. This rather short-term-oriented perspective explains, for example, misperceptions regarding long-term developments in the Islamic world, in peacebuilding processes (Langer and Brown, 2016; Reychler, 2015) or in the strategic partnership with China (Stumbaum and Xiong, 2012).

Engagement demands that non-western framings of history also be taken seriously (Tickner and Blaney, 2012: 18-19). Firstly, learning other benchmark dates or foundational events is required, calling for a thorough knowledge of histories and collective memories of other regions and societies, and the implications these may have until this day, including for their perception of and response to EU foreign policy. Historical experiences may be unrelated to western involvement, but can also be associated with imperialism, colonialism, violence and dispossession by Europe and the West. These dynamics are often concealed in European timeframes (Buzan and Lawson, 2014; Pasture, 2015; Shilliam, 2011), but are reflected in benchmark dates in other regions, e.g. commemorations of colonial suppression and independence fights, European conquest and other 'Echoes of Empire' (Nicolaïdis et al., 2015) - all affecting the external perceptions and judgements about current European involvement in 
other regions. Examples are various western military interventions, the 1916 Sykes-Picot Treaty drawing state borders in the Middle East, or the 'century of humiliation' in China. Engaging also means paying attention to other perceptions of time and to other developmental trajectories than evolution towards European-style modernity. Not only may modernity have a different starting point elsewhere and are there alternative trajectories towards it (Delanty and Rumford, 2005; Fisher Onar and Nicolaïdis, 2013); different perceptions exist of what modernity entails (Chakrabarty, 2007; Dirlik, 2003) and alternative or hybrid modernities can choose to revert to former traditions (Fisher Onar and Müftüler-Baç, 2011). Engagement not merely entails seeing current differences, but also the trial and error of using western ideologies in other regions (e.g. nationalism, socialism, liberalism, secularism, capitalism), resulting in a denouncing of what did/does not work and a turn to what did/does. The rise of Islamism constitutes such an alternative modernity: a multifaceted modern political current with societies, movements and parties in different areas developing variations of this trajectory (Fisher Onar and Müftüler-Baç, 2011; Rubin, 2013). Daesh for example takes hybridity to the extreme with its use of 'western' technology and social media on the one hand, but its turn to religion and rejection of state borders drawn by Europe on the other.

\section{Normative decentring}

Finnemore and Sikkink (1998: 891) define a norm as 'a standard of appropriate behaviour for actors with a given identity'. What is deemed acceptable not only changes over time, but also differs according to place (Postel-Vinay, 2008: 39-40), calling into question 'EUniversalism' (Nicolaïdis, 2015: 285) and any other claims to universality of specific normative mind-sets. 
Provincializing allows analysts to become aware of norm prioritisation and the often quite specific interpretation of a norm and its field of application. In the analysis of European foreign policy, the focus generally lies on norms that fit within European and western ideas of a liberal, pluralist order. In the previous section, we already referred to norms deriving from a certain idea of 'Enlightenment' and modernity that have underpinned European truth claims. Within the context of the EU's external relations, the focus is on norms which the EU 'seeks to advance in the wider world: democracy, the rule of law, the universality and indivisibility of human rights and fundamental freedoms, respect for human dignity, the principles of equality and solidarity [...]' (Article 21(1) Treaty on European Union). These norms also permeate the widespread NPE debate (Manners, 2002; Whitman, 2011), although some get much less attention, such as solidarity and dignity. Unpacking European assumptions about norms exposes that these are not necessarily universal, nor of universal priority, although often presented as such. This points to what Tocci (2008: 4) labelled as the 'serious pitfall that has bedevilled much of the literature on EU foreign policy: subjectivity and presumed universality'.

Provincializing also provides deeper insights into how prioritised norms are interpreted and applied. This can be seen in two of the dominant normative narratives in EU foreign policy: human rights and democracy. Provincializing human rights shows that attention for human rights is not only selective, but that 'first generation' civil and political rights are prioritised over 'second generation' economic, social and cultural or 'third generation' solidarity rights. Normative preoccupations also mainly revolve around individual liberties instead of collective rights (cf. infra) (Donnelly, 2007; Moyn, 2010; Zhang, 2012). Provincializing democracy equally shows that European attention for democracy is selective, reflects specific meanings and 
is evaluated within specific parameters (Lamont et al., 2015; Morozov, 2013; Youngs, 2015). For example, democracy is often analysed without taking into account the power of economic actors over democratically elected governments (e.g. influence of capital markets and 'Troika' on the 2015 Greek government).

Engagement requires that analysts learn about prioritised norms in other societies or regions and their specific interpretation and application. Additionally, the question rises how these norms relate to the European normative mind set, if they appear in European thinking at all. In order to allow for comparative analysis and to avoid the aforementioned dangers of knowledge fragmentation and 'othering', it can be analytically useful to position norms on continua of normative thinking, such as responsibilities-rights, individualism-collectivism, secularismreligiosity.

The first continuum is related to variations of the focus on rights and freedoms on the one hand and responsibilities and obligations on the other. Questions that arise are whether the emphasis is on responsibilities or rights (or both), whose responsibilities and rights are emphasised, and towards whom people or entities are responsible. When engaging, we learn that responsibilities towards society may be prioritised over the individual's personal freedom. Examples include obligations towards one's group being seen as morally superior to individual rights in Asian contexts (Zhang, 2012), or the discussion on duties versus rights in Islamic discourses (Orakzai, 2012). This contrasts with the current European/western focus on individual rights, often considered detached from responsibilities or obligations - although this has varied in different stages of Europe's history and still varies throughout European societies. 
Closely related is a second continuum between the individual and collective/relational. Norms can be derived from the intricate interrelation between the individual and the larger social group. Despite major differences between the historical and societal contexts in which these concepts arose, the southern African idea of ubuntu (Smith, 2012), the Russian term lichnost (Kharkhordin, 1999) and the Confusion concept guanxi (Pan, 2016) all reflect notions of relationality: an individual exists within and through a social context. Prioritizing the collective is then considered a fundamentally positive norm. 'Stability' or 'harmony', both in personal relations and in international order, can in this context be of higher priority than e.g. democracy or human rights, which can be considered as problematic if they lead to chaos or do not engender greater equality or social inclusion (Ding, 2012; Morozov, 2013). This focus on relationality also explains the prioritization of values such as 'justice' in the Mediterranean world (al-'adala or 'giving to each his due') (Ayubi, 2005: 18), 'respect' and 'honour', or mianzi or 'face' in Asian contexts.

A third continuum lies between secular and religious/spiritual. Within the context of western secularism and due to the Enlightenment's impact on normative presumptions, religion is a largely ignored category (Sheikh and Wæver, 2012; Wolff, 2015). However, as de Sousa Santos (2002: 48) notes, 'the secular-religious distinction is a distinctly Western one' and may be irrelevant within other normative mind-sets. Within the umma, the personal relationship with Allah is the principal overarching value, implying an array of norms associated with Islamic belief. In Buddhist and Hindu societies, dharma sees the individual primarily as part of a whole and rather than on rights or democracy, the focus lies on 'the primordial imperative, the duty of individuals to find their place in the order of the entire society and of the entire cosmos' (Ibid.: 
49). Both concepts point to a fundamental relationship with a divinity or cosmic order, with implications both for the (ir)relevance of norms promoted by EU foreign policy and how Europe and the West are perceived.

After adopting a more inclusive and comprehensive view on prioritised norms in Europe and in other regions, scholars can examine whether these norms and their relative hierarchy are similar, overlapping, complementary or competing. They can also assess whether the EU pays attention to norms which are considered crucial in other areas and whether this can help explain misunderstandings, failures or successes in European foreign policy.

\section{Polity decentring}

In this section, we employ the term 'polity', conceptualised by Ferguson and Mansbach (1996: 34) as political entities or authority structures that have 'a distinct identity; a capacity to mobilise persons and their resources for political purposes, that is, for value satisfaction; and a degree of institutionalisation and hierarchy (leaders and constituents)'. Underlying polities is an 'exchange phenomenon ${ }^{2}$ in which loyalties and other resources are provided in return for value satisfaction (or relief from value deprivation)' (Ferguson and Mansbach, 1996: 36). Providing the basis for the internal legitimacy of polities, this value satisfaction can be related to the provision of identity, order, security, and other vital public goods and services. It can be organised both horizontally (loyalty towards the group and mutual solidarity between its members) and vertically (loyalty and dependency between leading actors and group members) (Keukeleire and Lecocq, forthcoming).

\footnotetext{
${ }^{2}$ Italics by Ferguson and Mansbach (1996).
} 
Provincializing polity in the analysis of European foreign policy implies unpacking a specific set of predominant polities that reflect a Westphalian state-centric and modernity bias (Ferguson and Mansbach, 2000; Inayatullah and Blaney, 2004) (see temporal decentring). The state-centric bias means a focus on territorial sovereign states and relations between states (with governments as the most important agents), but also on polities based on states such as international organizations (including partly post-Westphalian polities, such as the EU itself). The modernity bias is reflected in the Weberian conception of the 'modern' state with its institutional and functional capacities and in the dominant western and European focus on individualism, citizenship and the distinctions between public/private, state/society and politics/religion. Taken together, both biases lead to assumptions about the state as the main point of reference as a legitimate authority structure and for providing identity, order, public goods and services.

Unpacking these assumptions requires an awareness of the long and difficult evolution and diversity that was and still is a reality within Europe and the West itself, and the fact that the 'ideal modern state' is more myth than reality. As Ferguson and Mansbach (2003: 25-26, 114) note, two major - apparently contradictory - trends continuously lead to a recession of state influence: on the one hand 'a growth of regional and global networks of authority that link people physically remote from one another [... but effectively] consolidate governance' such as international, regional and non-governmental organizations, and on the other hand, 'a fracturing of existing territorial states into smaller [...] islands of self-identification that localize authority and defy efforts to provide answers to the collective goods dilemma', as is demonstrated by the 'explosion of ethnic, religious, tribal and even "civilizational" self-identities'. This fracturing of existing states is also mirrored in the growing number of 'areas of limited statehood' (Risse, 
2011; Börzel and Risse, 2016) or supposedly 'ungoverned spaces' (Clunan and Trinkunas, 2010), steered by other types of polities and governance systems. Provincializing thus implies being conscious of what Agnew (1994: 77) calls the 'territorial trap', being the misconception of the 'historical relationship between territorial states and the broader social and economic structures and geopolitical order'.

Engagement requires taking into account and learning about and from a larger set of polities. Apart from states and international and regional organizations, engagement sheds light on various other sub- and transnational authority structures, which - although not only crucial determinants for local contexts, but sometimes also in international affairs - remain largely invisible in predominant political science frameworks. Apart from state-based polities, other polities based on i.a. ethnicity, religion, warlordism or combinations thereof emerge in areas of interest to the EU's neighbourhood and foreign policy. Ethnicity-based polities exist in diverse forms and are labelled ${ }^{3}$ differently in different regions, e.g. tribes and clans in the Middle East and North Africa (MENA) or Central Asia (i.a. Salzman, 2015) or ethnic groups, kingdoms or chiefdoms in sub-Sahara Africa (i.a. Chabal and Daloz, 1999). Religion-based polities are, for example, the broad array of Islamic networks ranging from the wide community of believers or umma, to movements such as the Muslim Brotherhood or, in its most radical form, Daesh (i.a. Rubin, 2013; Walby, 2004). Examples of warlordism-based polities are the myriad of warlords, their militias and armed non-state actors in conflict areas in the MENA, Central Asia and sub-

\footnotetext{
${ }^{3}$ Employing terminology related to clans or tribes is often criticised or rejected for being closely associated with (neo-)colonialism. However, these terms are used by these polities to describe themselves, and leaving the myriad of polities uncategorised leads to the abovementioned pitfalls of neglecting part of reality or being left with merely casespecific knowledge.
} 
Sahara Africa (i.a. Jackson, 2003; Marten, 2012). These various types of polities can 'overlap, layer, nest, and interact - coexist, cooperate, and conflict in the context of particular issues', reflecting their varying functions and degrees of reach over people, resources, space and issues (Ferguson and Mansbach, 2000: 29-30).

When assessing European foreign policy on e.g. democratisation, good governance or statebuilding, scholars may not only examine which political systems or regimes exist in another region. They may also gain insight in the existence, nature and effectiveness of other kinds of overlapping, layered or nested polities which are considered legitimate by parts of the population in this region and which provide identity, order, security and collective goods and services. For each of their features or functions, scholars can examine how they relate to the structures supported or promoted by European actors. Such comparative analysis can help explain the successes and failures of EU foreign policy in third regions or detect positive or negative side-effects of policies. It can make both scholars and EU practitioners pay attention to polities in a comprehensive way, beyond judgements about their 'traditional' or 'illegitimate' nature.

\section{Linguistic decentring}

Linguistic decentring is necessary, as 'any language by its structure, its metaphors and its vocabulary imposes a pattern of thought which reflects its parent culture' (Groom, 2005: 169170). Provincializing requires an awareness that the analysis of European foreign policy is embedded in and constrained by dominant linguistic frameworks in Europe and the West. A first aspect is the predominance of English in international scholarly debates (see also 
disciplinary decentring). English as a lingua franca facilitates international academic interaction, but may also inhibit the participation of scholars from other language groups. Related characteristics, as Wæver (1998: 694-695) emphasised, are the dominant stylistic criteria of 'the American brand of the Anglo-Saxon intellectual style, with brief, straightforward statements and linear progression of an argument'. Whereas this can be regarded as spelling out clarity, it may also act as a 'barrier to expressing real complexity' (Wæver, 1998: 694), engendering 'stylized Manichean representations of complex phenomena' (Fisher Onar and Nicolaïdis, 2013: 288).

Secondly, the majority of European foreign policy analysts rarely use primary and secondary sources in non-European languages such as Arabic, Farsi, Turkmen, Mandarin or Hausa. This implies that potentially relevant literature and data are neglected due to a linguistic barrier and that research on e.g. EU relations with China or the Arab world is often exclusively based on western sources, raising questions about the validity of produced conclusions. Even non-western scholars who convey their research in English often adapt their language to western or European audiences, or represent a distinct socio-economic or political background which is not always representative for their country or society.

Thirdly, European foreign policy analysts may be ignorant of basic concepts, ideas and approaches which are foreign to their own linguistic framework, conceptual lenses and cognitive world, but may be key to understanding other regions and the impact of the European foreign policy towards them. Major differences may also exist in manners of communicating, a problem which is not simply solved by translating non-European languages or concepts into European languages, as specific words may entail a different meaning depending on context, 
society, place and time. Chakrabarty (2007: 17) refers to the problem of 'translating diverse forms, practices, and understandings of life into universalist political-theoretical categories of deeply European origin', leading to “"rough translations" of native terms'.

Linguistic engagement thus implies analysing other regions and societies (and Europe's relations with and foreign policy towards them) from within local linguistic frameworks and contexts. This calls for collaboration with scholars who have sound knowledge of the local language(s) and an understanding of the broader linguistic and communicative context and related conceptual lenses, needed to unveil both fundamental meanings and subtle nuances. Especially the section on normative decentring included examples of meanings getting 'lost in translation' when adopting western terminology for complex non-western concepts (e.g. the meaning of al-adala and lichnost is not covered by 'justice' and 'individual'). Another example is the avoidance of the word 'no' in Asia and the use of indirect strategies to convey a refusal or disagreement vis-à-vis someone else, as these are less 'face-threatening' and in concordance with the basic value of 'harmony' and 'rejection avoidance' (Boonkongsaen, 2013; Hashimoto and Yamagishi, 2013) (see normative decentring). Differences like these, in the way interests and sensitivities are conveyed, could be revealed as factors influencing the (in)effectiveness of EU foreign policy.

\section{Disciplinary decentring}

To decentre on an epistemological and methodological level implies a consciousness that the analysis of Europe's foreign policy is not only embedded in the research traditions and theoretical perspectives of IR, Political Science, Foreign Policy and EU Studies (Jørgensen 
2015a, 2015b), but also constrained by them. Despite their often implicit universal scientific claims, they are rooted in specific European or western contexts, as they are 'the local product of a particular geo-epistemological perspective' (Wæver and Tickner 2009). This also explains why they are often insufficient for understanding issues and challenges faced by other parts of the world, which nevertheless also impact upon Europe and European foreign policy.

Provincializing therefore requires an awareness of the limited receptivity to 'difference' by the predominant research practices and methodological approaches in Political Science, IR and EU Studies. Chabal and Daloz (2006: 12-13) make the important point that the usual a priori definition of a conceptual framework and research questions can be detrimental to seeing difference, as this 'inevitably tends to privilege ethnocentric conceptual frameworks over those that may be argued to be more appropriate for non-Western, or non-industrial societies'. Relevant here is Hudson's (2007: 188) complaint about the continued use of 'inappropriate methods, by employing simplifying assumptions that evade the complexity with which the methods cannot cope'.

Openness to difference is also hampered by the (explicit or implicit) positivist approach, the prioritization of explanatory research, and the quest for theory-building (Chabal and Daloz, 2006; Thomas and Wilkin, 2006). Although the search for causal relations and explanations may in principle be considered epistemologically preferable to descriptive or exploratory analysis, a major drawback is the resulting tendency to disregard important entities and phenomena which are less easily explained and for which data are more difficult to obtain (see the various examples in the sections on normative decentring and polity decentring). In reference to linguistic decentring, the fact that most research on European foreign policy is 
mainly or solely based on western primary and secondary sources is also mirrored in the limited number of references to and publications by non-western scholars (Keuleers et al., 2016). What Shilliam (2011) and Tickner (2013) labelled as imperialist core-periphery power relations in IR, may in this sense also be reflected in scholarship on EU foreign policy.

Disciplinary engagement follows rather logically from provincializing, providing remedies to the limitations that came to the fore. On a theoretical level, a first step is incorporating more insights from post-positivist approaches with a larger openness for difference (e.g. Subaltern studies, post-colonial or post-modernization theories). Although a 'non-western IR theory' may not exist (Buzan and Acharya, 2010; Tickner and Wæver, 2009), western scholars can actively seek to learn conceptualizations offered by scholars in the Arab world, Africa, Asia and other areas and engage with different readings of concepts such as democracy, security or sovereignty (see case-studies in Morozov, 2013; Pan, 2012; Tickner and Blaney, 2012), but also with lesser known notions such as guanxi or ubuntu. Engaging with non-western scholars and literature can also help European foreign policy specialists to pay attention to a wider set of relevant research problems and questions.

Another step to strengthen engagement is to learn from other academic disciplines and their methodologies, including from how these disciplines evolved and are practiced in other parts of the world. An essential part of this much-needed interdisciplinarity is closer interaction with the already multidisciplinary area studies, which has often been accused of 'epistemological inferiority' (Tickner and Blaney, 2012: 8). This interaction is essential to obtain deeply needed basic information and to gain an understanding of phenomena that are largely unknown to scholars specialised in European foreign policy. Reaching out to local knowledge is thus 
essential (Kalb, 2006), though not always easy. Standard research guidelines in political science can prove to be of limited use, if only because of the difficulty of obtaining data and using local sources. Methodologies used in disciplines such as anthropology - including field work and (non-)participant observation - can be needed for data collection and for grounding the analysis in the interpretation of what makes sense within contexts of other societies or regions. However, this involves a range of specific methodological, ethical, linguistic, financial, logistical and even security challenges, which explains why such disciplinary reconstruction can be very challenging in practice, even when scholars fully acknowledge its necessity (Chabal and Daloz, 2006; Kapiszewski et al., 2015; Olivier de Sardan, 2015).

\section{Concluding remarks: developing the Decentring Agenda}

How can scholars apply the analytical framework presented in this article? In view of its complexity and comprehensiveness and the need to explore unknown terrain, researchers will generally not be able to tackle decentring in all its dimensions and categories, except through large interdisciplinary projects. However, interesting and innovative research can be conducted when scholars focus on only one or a few categories and the interactions between them. The framework can support them in developing a wide range of research topics, questions and approaches that can be relevant in the analysis of European foreign policy, other than those that are currently dominating the field.

What are the next steps in this framework's development? First, it serves as a basis for further elaboration, adaptation and sharpening of the various analytical dimensions, (sub)categories and points of attention. Scholars may explore the relevance of additional decentring categories, such 
as cultural decentring (now partially included in other categories), gender decentring or class decentring (see case-studies in Huber and Kamel, 2016). In addition, they can further refine the 'theoretical case for a research agenda with more attention for outside-in approaches' (Dijkstra and Vanhoonacker, 2017: 281).

Second, scholars can apply the analytical framework on specific case-studies. In turn, these can contribute to developing and refining it, allowing us to judge whether this framework for operationalizing the Decenting Agenda can indeed help 'students of global order - and Europe's place therein - to better grasp the challenges and opportunities of our increasingly nonEuropean and post western order' (Fisher Onar and Nicolaïdis, 2013: 296-297) and to better understand how to deal with the multiple crises in the EU's foreign policy (Müller, 2016).

And third, as this article focuses mostly on provincializing and engagement, a following step is to explore how these can be the basis for reconstruction or the renewal of EU external action based on humility, empowerment, mutuality (Fisher Onar and Nicolaïdis, 2013) and above all, as defined in the EU Global Strategy, on a 'deeper situational awareness' (Mogherini, 2016: 48) - by both scholars and practitioners - of a world that is increasingly 'connected, contested and complex' (Mogherini, 2015).

\section{References}

Agnew J (1994) The Territorial Trap: The Geographical Assumptions of International Relations Theory. Review of International Political Economy 1(1): 53-80.

Al-Rodhan NRF (2009) Neo-statecraft and Meta-geopolitics. Münster: LIT Verlag. 
Bach DC (2011) Patrimonialism and Neopatrimonialism: Comparative Trajectories and Readings. Commonwealth and Comparative Politics 49(3): 275-294.

Birth K (2016) Time Blind. Problems in Perceiving Other Temporalities. Basingstoke: Palgrave Macmillan.

Bischoff P-H, Aning K and Acharya A (2016) (eds) Africa in Global International Relations. London: Routledge.

Boonkongsaen N (2013) Filipinos and Thais Saying "no" in English. Manusya Journal of Humanities 16(1): 23-40.

Börzel T A, Dandashly A and Risse T (eds) (2015) Special Issue: Responses to the 'Arabellions': The EU in Comparative Perspective. Journal of European Integration 37(1).

Börzel, T A and Risse T (2016) Dysfunctional state institutions, trust, and governance in areas of limited statehood. Regulation \& Governance 10(2): 149-160

Buzan B and Acharya A (2010) Non-Western International Relations Theory. Abingdon: Routledge.

Buzan B and Lawson G (2014) Rethinking Benchmark Dates in International Relations. European Journal of International Relations 20(2): 437-462.

Buzan B and Little R (2000) International Systems in World History. Oxford: Oxford University Press.

Cavatorta F and Pace M (2010) The Post-normative Turn in European Union (EU)-Middle East and North Africa (MENA) Relations: An Introduction. European Foreign Affairs Review 15(5): 581-587.

Chabal P and Daloz J-P (1999) Africa works: disorder as political instrument. Bloomington: Indiana University Press.

Chabal P and Daloz J-P (2006) Culture Troubles: Politics and the Interpretation of Meaning. London: Hurst \& $\mathrm{C}^{\circ}$.

Chaban N and Holland M (2013) Seeing the EU from Outside its Borders, Baltic Journal of European Studies 3(3): 3-14. 
Chakrabarty D (2007) Provincializing Europe. Postcolonial Thought and Historical Difference. Princeton: Princeton University Press.

Chen Z (2016) China, the European Union and the Fragile World Order. Journal of Common Market Studies 54(4): 775-792.

Cole J (2013) A Geography of the European Union. London: Routledge.

Clunan A and Trinkunas HA (2010) Ungoverned Spaces. Stanford: Stanford University Press.

de Sousa Santos B (2002) Towards a Multicultural Conception of Human Rights. In: Hernández-Truyol B (ed.) Moral Imperialism. New York: New York University Press, pp. 39-60.

Delanty G and Rumford C (2005) Rethinking Europe. London: Routledge.

Diez T (2013) Normative power as hegemony. Cooperation and Conflict 48(2): 194-210.

Dijkstra H and Vanhoonacker S (2017) Why study EU foreign policy at all? A response to Keuleers, Fonck and Keukeleire. Cooperation and Conflict 52(2): 280-286.

Ding C (2012) Conceptual Gaps on Stability in Chinese and European Contexts. In: Pan Z (ed.) Conceptual gaps in China-EU Relations. Basingstoke: Palgrave Macmillan, pp. 128-140.

Dirlik A (2003) Global modernity? Modernity in an age of global capitalism. European Journal of Social Theory 6(3): 275-292.

Donnelly J (2007) The Relative Universality of Human Rights. Human Rights Quarterly 29(2): 281-306.

Ejdus $\mathrm{F}$ and Juncos $\mathrm{AE}$ (eds) (forthcoming) Special Issue: Local perspectives on EU peacebuilding: Effectiveness, ownership and resistance. Contemporary Security Policy.

Erdmann G and Engel U (2007) Neopatrimonialism reconsidered. Commonwealth and Comparative Politics 45(1): 95-119.

Ferguson YH and Mansbach RW (1996) Polities: Authority, Identities, and Change. Columbia: University of South Carolina Press. 
Ferguson YH and Mansbach RW (2000) What is a Polity? A Roundtable. International Studies Review 2(1): 3-31.

Ferguson YH and Mansbach RW (2003) The Elusive Quest Continues: Theory and Global Politics. New Jersey: Pearson Education.

Finnemore M and Sikkink K (1998) International Norm Dynamics and Political Change. International Organization 52(4): 887-917.

Fisher Onar N and Müftüler-Baç M (2011) The Adultery and Headscarf Debates in Turkey: Fusing "EUniversal” and “Alternative” Modernities? Women's Studies International Forum 34(5): 378-389.

Fisher Onar N and Nicolaïdis K (2013) The Decentring Agenda: Europe as a post-colonial power. Cooperation and Conflict 48(2): 283-303.

Fukuyama F (2011) The Origins of Political Order. New York: Farrar, Strauss and Giroux.

Groom J (2005) International Relations in France: a View from Across the Channel. European Political Science 4: 164-74.

Hashimoto H and Yamagishi T (2013) Two Faces of Interdependence: Harmony seeking and rejection avoidance. Asian Journal of Social Psychology 16(2): 142-151.

Huber D and Kamel L (eds) (2016) Arab Spring and Peripheries. A Decentring Research Agenda. London: Routledge, 2016.

Hudson VM (2007) Foreign Policy Analysis. New York: Rowman \& Littlefield.

Inayatullah N and Blaney DL (2004) International Relations and the Problem of Difference. London: Routledge.

Jackson P (2003) Warlords as alternative forms of governance. Small Wars and Insurgencies 14(2): 131150.

Jørgensen KE (2010) International Relations Theory. A New Introduction. Basingstoke: Palgrave Macmillan. 
Jørgensen KE (2015a) Introduction: Research Traditions. In Jørgensen KE et al. (eds) The SAGE Handbook of European Foreign Policy. London: Sage, pp. 3-13.

Jørgensen KE (2015b) The Study of European Foreign Policy: Trends and Advances. Jørgensen KE et al. (eds), The SAGE Handbook of European Foreign Policy, London: Sage, pp. 14-29.

Jørgensen KE, Aarstad AK, Drieskens E, Laatikainen K. and Tonra B (eds) (2015) The SAGE Handbook of European Foreign Policy. London: Sage.

Kalb D (2006) Uses of Local Knowledge. In: Goodin RE and Tilly C (eds) The Oxford Handbook of Contextual Political Analysis. Oxford: Oxford University Press, pp. 579-594.

Kapiszewski D, MacLean LM and Read BL (2015) Field Research in Political Science. Practices and Principles. Cambridge: Cambridge University Press.

Keukeleire S (2014) Lessons for the Practice and Analysis of EU Diplomacy from an "Outside-In" Perspective. In: Gstöhl S and Lannon E (eds), The Neighbours of the European Union's Neighbours. Surrey: Ashgate, pp. 227-241.

Keukeleire S and Lecocq S (forthcoming) Legitimacy and decentring the analysis of EU foreign policy: (re-) introducing "Polity". In Tonra B, Raube K and Sjursen H (eds) Special Issue: Legitimacy and EU Foreign Policy. Global Affairs.

Keukeleire S and Thépaut C (2012) Towards an Outside-in Approach in the analysis of (European) Foreign Policy. In: The European Union in International Affairs III, Brussels, Belgium, 3-5 May 2012.

Keuleers F, Fonck D and Keukeleire S (2016) Beyond EU Navel-gazing: Taking Stock of EU-centrism in the Analysis of EU Foreign Policy. Cooperation and Conflict 51(3): 1-20.

Kharkhordin O (1999) The Collective and the Individual in Russia. Berkeley: University of California Press. 
Lamont CK, van der Harst J and Gaenssmantel F (2015) (eds) Non-Western Encounters with Democratization. Farnham: Ashgate.

Langer A and Brown G. (eds) (2016) Building Sustainable Peace. Timing and Sequencing of PostConflict Reconstruction and Peacebuilding. Oxford: Oxford University Press.

Lucarelli S and Fioramonti L (eds) (2009) External Perceptions of the European Union as a Global Actor. London: Routledge.

Manners I (2002) Normative Power Europe: a Contradiction in terms? Journal of Common Market Studies 40(2): 235-258.

Marten K (2012) Warlords: Strong-arm Brokers in Weak States. Ithaka: Cornell University Press.

Mayer H and Zielonka J (2012) Europe as a Global Power: View from Outside. Perspectives 20(2): 5129.

Mogherini F (2015) The European Union in a changing global environment: A more connected, contested and complex world. Brussels.

Mogherini F (2016). Shared vision, common action: a stronger Europe: A global strategy for the European Union's foreign and security policy. Brussels.

Morozov V (ed.) (2013) Decentring the West. The Idea of Democracy and the Struggle for Hegemony. Surrey: Ashgate.

Moyn S (2010) The Last Utopia: Human Rights in History. Cambridge: Harvard University Press.

Müller P (2016) EU foreign policy: No major breakthrough despite multiple crises. Journal of European Integration 38(3): 359-374.

Nayak M and Selbin E (2010) Decentering International Relations. London: Zed Books.

Nicolaïdis K, Sèbe B and Maas G. (2015) (eds) Echoes of Empire: Memory, Identity and Colonial Legacies. London: Tauris. 
Nicolaïdis K (2015) Southern Barbarians? A Post-Colonial Critique of EUniversalism. In Nicolaïdis K et al. (eds) Echoes of Empire. London: Tauris, pp. 283-303.

Olivier de Sardan J-P (2015) Epistemology, Fieldwork and Anthropology. Basingstoke: Palgrave Macmillan.

Orakzai SB (2012) Alternative Discourse on Human Rights. In Bennett S and O'Brien E (eds), What Future for Human Rights in a Non-Western World? London: Human Rights Consortium, pp. 7788.

Pan Z (ed.) (2012) Conceptual Gaps in China-EU Relations, Basingstoke: Palgrave Macmillan.

Pan Z (2016) Guanxi, Weiqi and Chinese Strategic Thinking. Chinese Political Science Review 1(2): $303-$ 321.

Pasture P (2015) Imagining European Unity since 1000 AD. Basingstoke: Palgrave Macmillan.

Postel-Vinay K (2008) The Historicity of European Normative Power. In Laïdi Z (ed.) EU Foreign Policy in a Globalized World. London: Routledge, pp. 38-47.

Reychler L (2015) Time For Peace: The Essential Role of Time in Conflict and Peace Processes, Brisbane: University of Queensland Press.

Risse T (ed.) (2011) Governance Without a State? New York: Columbia University Press.

Rubin B (ed.) (2013) Islamic Political and Social Movements. London: Routledge.

Salzman PC (2015) Tribes Today: In Anthropology and in the World. The Journal of the Middle East and Africa 6(3-4): 353-364.

Sheikh MK and Wæver O (2012) Western Secularisms: Variation in a Doctrine and its Practice. In Tickner AB and Blaney DL (eds), Thinking International Relations Differently. London: Routledge, pp. 275-298.

Shilliam R (ed.) (2011) International Relations and Non-Western Thought, London: Routledge. 
Sjursen, H. (2006) The EU as a 'Normative' Power: How Can This Be? Journal of European Public Policy 13(2): 235-251.

Smith K (2012) Contrived Boundaries, Kinship and Ubuntu: a (South) African View on the "International". In: Tickner AB and Blaney DL (eds) Thinking International Relations Differently. London: Routledge, pp. 301-321.

Staeger . (2016) Africa-EU Relations and Normative Power Europe: A Decolonial Pan-African Critique. Journal of Common Market Studies 54(4): 981-998.

Stumbaum M-B and Xiong W (2012) Conceptual Differences of Strategic Partnership in EU-China Relations. In: Pan Z (ed.) Conceptual Gaps in China-EU Relations, Basingstoke: Palgrave Macmillan, pp. 156-172.

Taylor C (2002) Modern Social Imaginaries. Public Culture 14(1): 91-124.

Therborn G (2006) Why and how place matters. In Tilly C and Goodin RE (eds) The Oxford Handbook of Contextual Political Analysis. Oxford: Oxford University Press, pp. 509-533.

Thomas C and Wilkin P (2004) Still Waiting after all these Years: "The Third World" on the Periphery of International Relations. British Journal of Politics and International Relations 6(2): 241-258.

Tickner AB (2003) Seeing IR Differently: Notes from the Third World. Millennium 32(2): 295-324.

Tickner AB (2013) Core, Periphery and (Neo)Imperialist International Relations. European Journal of International Relations 19(3): 627-646.

Tickner AB and Blaney DL (eds) (2012) Thinking International Relations Differently. London: Routledge.

Tickner AB and Wæver O (eds) (2009) International Relations Scholarship Around the World. London: Routledge.

Tocci N (ed.) (2008) Who is a Normative Policy Actor Brussels: CEPS.

Verloo M (ed.) (2007) Multiple Meanings of Gender Equality. Budapest: CPS Books. 
Wæver O (1998) The Sociology of a Not So International Discipline: American and European Developments in International Relations. International Organization 52(4): 687-727.

Wæver O and Tickner AB (2009) Introduction: Geocultural Epistemologies. In: Tickner AB and Wæver O (eds) International Relations Scholarship Around the World, London: Routledge, pp. 1-31.

Walby S (2004) No one Polity Saturates the Political Space in a Given Territory. Sociology 38(5): 10351042.

Whitman RG (2011) (ed.) Normative Power Europe. Basingstoke: Palgrave Macmillan.

Wolff S (2015) US and EU Engagement with Islamists in the Middle East and North Africa. Transatlantic Academy Paper 3.

Youngs R (2015) The Puzzle of Non-Western Democracy. Washington: Carnegie.

Zhang C (2012) The Conceptual Gap on Human Rights in China-Europe Relations. In: Pan Z (ed.) Conceptual Gaps in China-EU Relations. London: Palgrave Macmillan, pp. 83-97. 
Table 1: Operationalizing the Decentring Agenda ${ }^{a}$

\begin{tabular}{|c|c|c|}
\hline DECENTRING & Provincializing & Engagement \\
\hline & $\begin{array}{l}\text { Questioning Eurocentric accounts } \\
\text { and the myth of Eurocentric } \\
\text { civilizational primacy }\end{array}$ & $\begin{array}{l}\text { Learning from the other and } \\
\text { engaging with others' perspectives } \\
\text { and assumptions }\end{array}$ \\
\hline Spatial & $\begin{array}{l}\text { - } \quad \text { European/western } \\
\text { geographical features } \\
\text { - } \quad \text { European/western material } \\
\text { situation }\end{array}$ & $\begin{array}{l}\text { - Geographical features of } \\
\text { other spaces } \\
\text { - Other spatial and material } \\
\text { contexts }\end{array}$ \\
\hline Temporal & 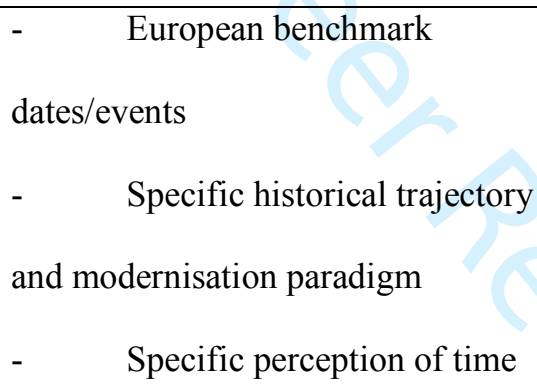 & $\begin{array}{l}\text { - Other benchmark } \\
\text { dates/events } \\
\text { - Other developmental } \\
\text { trajectories and pathways to } \\
\text { 'modernity' (hybridity) }\end{array}$ \\
\hline Normative & $\begin{array}{l}\text { Pluralist or liberal norms } \\
\text { - } \quad \text { Universality? } \\
\text { - } \quad \text { Interpretation? } \\
\text { - } \quad \text { Application? } \\
\text { - } \quad \text { Prioritization/hierarchy? }\end{array}$ & $\begin{array}{l}\text { Other (prioritised) norms } \\
-\quad \text { Rights and responsibilities } \\
\text { - } \quad \text { Individualism and } \\
\text { collectivism/relationality } \\
\text { - } \quad \text { Secularism and } \\
\text { religiosity/spirituality }\end{array}$ \\
\hline
\end{tabular}




\begin{tabular}{|c|c|c|}
\hline Polity & $\begin{array}{ll}- & \text { State-centric bias } \\
- & \text { Modernity bias }\end{array}$ & $\begin{array}{l}\text { Different polity types based on } \\
-\quad \text { states } \\
-\quad \text { ethnicity } \\
-\quad \text { religion } \\
-\quad \text { warlordism }\end{array}$ \\
\hline Linguistic & $\begin{array}{ll}- & \text { English as lingua franca } \\
- & \text { Stylistic criteria } \\
- & \text { Rough translations } \\
-\quad & \text { Reliance on English/western } \\
\text { sources }\end{array}$ & 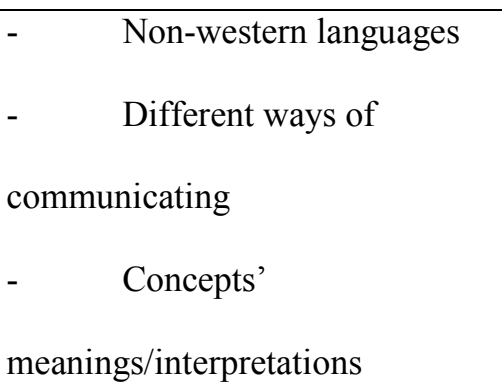 \\
\hline Disciplinary & $\begin{array}{l}\text { Constraints of } \\
-\quad \text { Theoretical perspectives } \\
-\quad \text { Research practices } \\
-\quad \text { Positivist approaches } \\
-\quad \text { Dominant use } \\
\text { western/European sources }\end{array}$ & $\begin{array}{l}\text { Learning through } \\
\text { - } \quad \text { Multi-disciplinarity } \\
\text { - } \quad \text { Area studies (also } \\
\text { descriptive work) } \\
\text { - } \\
\text { Non-positivist approaches } \\
\text { Local empirical work }\end{array}$ \\
\hline
\end{tabular}

${ }^{a}$ This table combines the provincializing and engagement dimensions as proposed by Fisher Onar and Nicolaïdis (2013) with the six decentring categories developed by the authors of this article. 
Table 1: Operationalizing the Decentring Agenda ${ }^{1}$

\begin{tabular}{|c|c|c|}
\hline DECENTRING & Provincializing & Engagement \\
\hline & $\begin{array}{l}\text { Questioning Eurocentric accounts and the } \\
\text { myth of Eurocentric civilizational primacy }\end{array}$ & $\begin{array}{l}\text { Learning from the other and engaging with } \\
\text { others' perspectives and assumptions }\end{array}$ \\
\hline Spatial & $\begin{array}{l}\text { - European/Western geographical features } \\
\text { - European/Western material situation }\end{array}$ & $\begin{array}{l}\text { - Geographical features of other spaces } \\
\text { - Other spatial and material contexts }\end{array}$ \\
\hline Temporal & $\begin{array}{l}\text { - } \text { European benchmark dates/events } \\
\text { - Specific historical trajectory and } \\
\text { modernisation paradigm } \\
\text { - Specific perception of time }\end{array}$ & $\begin{array}{l}\text { - Other benchmark dates/events } \\
\text { - Other developmental trajectories and } \\
\text { pathways to 'modernity' (hybridity) } \\
\text { - Other perceptions of time }\end{array}$ \\
\hline Normative & $\begin{array}{l}\text { Pluralist or liberal norms } \\
\text { - Universality? } \\
\text { - Interpretation? } \\
\text { - Application? } \\
\text { - Prioritization/hierarchy? }\end{array}$ & $\begin{array}{l}\text { Other (prioritised) norms } \\
\text { - Rights and responsibilities } \\
\text { - Individualism and } \\
\text { collectivism/relationality } \\
\text { - Secularism and religiosity/spirituality }\end{array}$ \\
\hline Polity & $\begin{array}{l}\text { - State-centric bias } \\
\text { - Modernity bias }\end{array}$ & $\begin{array}{l}\text { Different polity types based on e.g. } \\
\text { - } \text { states } \\
\text { - } \text { ethnicity } \\
\text { - } \text { religion } \\
\text { - } \text { warlordism }\end{array}$ \\
\hline Linguistic & $\begin{array}{l}\text { - English as lingua franca } \\
\text { - Stylistic criteria } \\
\text { - Rough translations } \\
\text { - Reliance on English/Western sources }\end{array}$ & $\begin{array}{l}\text { - } \text { Non-Western languages } \\
\text { - Different ways of communicating } \\
\text { - Concepts' meanings/interpretations }\end{array}$ \\
\hline Disciplinary & $\begin{array}{l}\text { Constraints of } \\
\text { - } \text { Theoretical perspectives } \\
\text { - Research practices } \\
\text { - Positivist approaches } \\
\text { - Dominant use Western/European } \\
\text { sources }\end{array}$ & $\begin{array}{l}\text { Learning through } \\
\text { - Multi-disciplinarity } \\
\text { - } \text { Area studies (also descriptive work) } \\
\text { - } \quad \text { Non-positivist approaches } \\
\text { - } \quad \text { Local empirical work }\end{array}$ \\
\hline
\end{tabular}

\footnotetext{
${ }^{1}$ This table combines the provincializing and engagement dimensions as proposed by Fisher Onar and Nicolaïdis (2013) with the six decentring categories developed by the authors of this article
} 


\section{Introduction}

In The Decentring Agenda: Europe as a post-colonial power, Fisher Onar and Nicolaïdis (2013: 283) call for 'a paradigm shift that decentres the study and practice of Europe's international relations ... necessary both to make sense of our multipolar order and to reconstitute European agency in a non-European world' ${ }^{1}$. Their plea fits within a broader academic debate about the need to overcome Eurocentrism and to decentre Europe, the West and the International Relations (IR) discipline (Chakrabarty, 2000; Jørgensen, 2010; Morozov, 2013; Nayak and Selbin, 2010), to open_up for 'difference' (Inayatullah and Blaney, 2004; Tickner and Blaney, 2012) and to explore non-western IR theories and approaches (Acharya and Buzan, 2010; Bischoff et al., 2016; Tickner and Wæver, 2009). This plea is also reflected in the development of the 'local turn' in peacebuilding (Mac Ginty \& Richmond, 2013) and in critical analyses of the 'Arab spring' (Huber and Kamel, 2016), state making (Bartelson et al., forthcoming) and international interventions in general (see the contributions in this special issue - Schröder, 2018).

When focussing on the literature on Europe's international relations, some strands clearly go beyond Eurocentric accounts, such as the external perceptions literature (Chaban and Holland, 2013; Ejdus and Juncos, 2018; Lucarelli and Fioramonti, 2010; Mayer and Zielonka, 2012), assessments of the Normative Power Europe (NPE) concept that point to its Eurocentric

\footnotetext{
${ }^{1}$ For the difference and relationship between the terms 'Europe' and 'the West' and 'Eurocentrism' and 'westerncentrism', see Fisher Onar and Nicolaïdis (2013: 284). We mainly refer to 'Europe(an)' and 'Eurocentrism', acknowledging that these are largely embedded within the broader 'western' context. For an analysis of the different dimensions of Europe's international relations and European foreign policy, see Keukeleire and Delreux (2014: 1119).
} 
discourse (Diez, 2013; Sjursen, 2006; Staeger, 2016), and specific publications on the policy of the European Union (EU) towards the Arab world (Börzel et al., 2015; Cavatorta and Pace, 2010) or China (Chen, 2016; Pan, 2012). Nevertheless, these are exceptions. Eurocentrism remains predominant in the analysis of European foreign policy (Keuleers et al., 2016), which raises questions about the relevance of a scholarship on foreign policy that is rather inwardlooking and from which the 'foreign' is largely missing.

However, a framework for the systematic analysis of what 'difference' may entail and what it means to go beyond a Eurocentric perspective has not yet been developed. The purpose of this article is to provide an analytical framework to support scholars of European foreign policy in overcoming Eurocentrism and opening up for difference in a systematic way by operationalizing the Decentring Agenda. It offers an invitation as well as guidance to "critically unpack extant categories and assumptions at the level of ontology and epistemology" (Fisher Onar and Nicolaïdis 2013: 295).

\section{Operationalizing the Decentring Agenda: building blocks and challenges}

Building on earlier ventures into analysing European foreign policy from the outside (Keukeleire, 2014; Keukeleire and Thépaut, 2012), we propose six partially overlapping and coconstitutive categories for decentring (Table 1). The first five categories deal with ontological questions: spatial decentring mainly refers to material context, while time, norms, polity and language tackle immaterial contextual factors. These categories - and further developed subcategories - allow us to systematically cover major facets of what 'difference' may entail 
and what it may look like to go beyond a Eurocentric perspective. A separate sixth category is disciplinary decentring, focusing on epistemological and methodological challenges.

For each of the categories, we focus mainly on two analytical dimensions proposed by Fisher Onar and Nicolaïdis (2013) in their Decentring Agenda: provincializing and engagement. Provincializing means 'to unpack the social scientific categories, assumptions and paradigms that underpin Eurocentric truth claims' and to question 'Eurocentric accounts of world history and politics' as well as 'Eurocentric “civilizational” assumptions'. Engagement implies learning about and from others' perspectives and accounts of the world and engaging with the assumptions, worldviews and value systems that underpin them (Fisher Onar and Nicolaïdis, 2013: 286). In this article, we assess how both dimensions can be tackled in the analysis of European foreign policy (Table 1), in view of future research that can yield insights and policy recommendations for reconstruction or 'renewing of EU praxis in a non-European world, from the outside in' (Fisher Onar and Nicolaïdis, 2013: 286).

Table 1

Decentring is not without pitfalls and challenges. A first obvious challenge is that most western scholars are trained within western IR paradigms or the conventionally Eurocentric field of European Studies. How can they systematically engage in decentring, while being inherently part of a 'Eurocentric box', shaped by a western-centric intellectual and cultural legacy? There is a normal tendency to revert to known frames of reference or to filter out ideas which although important in non-European/western contexts - do not resonate with the analyst's own 
ontological, epistemological or linguistic framework, or are undetectable by conventional methodological approaches (Fisher Onar and Nicolaïdis, 2013: 285, 290). The subcategories in our framework aim to support scholars in overcoming this pitfall. Scholars, however, need to be aware that also conscious attempts to decentre cannot completely escape the asymmetrical international hierarchies in knowledge production (Agnew, 2007).

Secondly, a clear distinction should be made between the Decentring Agenda as an analytical or heuristic tool on the one hand, and as a normative judgement on the other. The aim is to assist scholars in detecting, labelling and understanding concepts, ideas and practices that do not fit within their usual frames of reference, without making a priori normative judgements.

Third, one must prevent decentring from leading to simplifications and 'othering' or overemphasising or artificially creating difference between 'the West' and 'the Rest' - a recurrent theme in various articles in this special issue (Schröder, 2018). As Morozov (2013: xiii) emphasises, 'the border between the West and the non-West is not a geographical one - it runs across societies and shapes our national and social identities'. Areas and societies are characterised by a high degree of complexity and hybridity: several processes and realities can exist in parallel, can be overlapping or separated, compatible or incompatible, mutually reinforcing or undermining, visible or invisible, and dynamic in space and time. Decentring can help increase receptivity to this complexity, which exists not only outside but also within Europe and the West.

A fourth challenge is avoiding that decentring merely leads to case-specific knowledge, without relevance for other cases or the potential for comparative analysis or generalisation. The inherent limitations of the abstract level are then swapped for the constraints of ad-hoc 
knowledge. This calls for pursuing a middle level of categorisation. Following the approach of Chabal and Dalloz (2006: 22), the aim here is to develop a framework which can be applied 'to widely divergent cases, in different areas, and enabling the analyst to [assess both] singularities and commonalities' and translate 'local [...] accounts into a language that is amenable to comparison with other cases'.

This article aims to provide an applicable analytical framework for decentring by proposing conceptual lenses and categorizations that facilitate seeing and understanding dynamics and realities that are not easily captured with predominant assumptions, theories and methods, while trying to avoid simplifications and knowledge fragmentation. In this article, we mainly focus on the four immaterial decentring categories and on disciplinary decentring; however, as a preliminary analytical step, analysts should consider 'space' and 'spatial decentring' to form an idea of the material context of the region under examination.

\section{Spatial decentring}

As Therborn asserts, 'politics begins with place [and] the Western notion of politics derives from a particular place and the concerns of its inhabitants' (Therborn, 2006: 509). Spatial decentring therefore looks into the basic geographic and material features of a society, country or region - geographical location and size, topographical aspects, environment, natural resources, etc. - and the way 'space' is organised and perceived, both internally and in relationship to other 'spaces'. This includes infrastructure, availability of public goods and services, socio-economic features, demography, etc. (Al-Rodhan, 2009; Tickner, 2003). 
Al-Rodhan's (2009) work on 'meta-geopolitics' provides a useful categorisation of features that determine how space is organised. As a systematic analysis of these features is beyond the scope of this article, we only point in general terms to what spatial provincializing can imply. It means acknowledging that European foreign policy analysts see the world from within a particular European/western geographic and spatial setting, involving assumptions about how the world is or should be organised. The European conceptualisation of space is characterised by the 'territorial trap' (see polity decentring; Agnew, 1994), as well as by some basic features of Europe's geographic and spatial context (Cole, 2013) which may not be taken for granted elsewhere.

Engagement and reconstruction require that analysts learn about and take into account the various spatial and geographic features of other areas, and that they try to understand their impact and potential influence on the (in)effectiveness of European foreign policy. For example, when analysing the EU's policy towards Libya (including the EU's Integrated Border Assistance Mission) scholars should take into account the country's geographic features, consisting largely of desert and with a $4350 \mathrm{~km}$ border and $1770 \mathrm{~km}$ coastline. And are we fully aware of the practical implications of the EU's call for elections in a country such as the DR Congo, which is half the size of Europe itself, with limited transportation infrastructure, rather weak administration and a low level of literacy?

\section{Temporal decentring}

Temporal provincializing implies an awareness that in the analysis of European foreign policy, a Eurocentric framing of history is often generalised to other parts of the world or is taken as a 
point of departure for assessing Europe's relations with and policies towards other regions. Firstly, modern Europe's experiences are reflected in an 'orthodox set' of benchmark dates or foundational events that took place in Europe or the broader West (Chakrabarty, 2007: 7). Buzan and Lawson (2014) point to the opening of sea lanes from Europe to the Americas and Indian Ocean in 1500, the 1648 Treaty of Westphalia, WWI and WWII, the start and end of the Cold War, and ' $9 / 11$ '. These events are related to specific historical experiences, collective memories and lessons learnt, also regarding Europe's external relations and policies - e.g. the benchmark of opening the sea lanes reflects an imperialist, colonialist European perspective. The analysis of EU foreign policy also takes as major reference points foundational EU-related events, such as the start of European integration (partly responding to the world wars) or the Maastricht and Lisbon Treaty (creating the Common Foreign and Security Policy, and the European External Action Service and High Representative/Vice-President of the European Commission function, respectively).

Secondly, provincializing implies acknowledging the specificity of Europe's historical trajectory. Chakrabarty (2007) and Bhambra (2007) highlight that western social science and social theory are generally inscribed within a modernity paradigm in which evolution is thought of as fundamentally progressive, emerging and developing first in Europe, but having a universal orientation. This specific idea of modernity is defined by Taylor (2002: 92) as 'new practices and institutional forms (science, technology, industrial production, urbanization) and new ways of living (individualism, secularization, instrumental rationality)'. It is seen as the basis for 'European political modernity' (Fischer Onar and Müftüler-Baç, 2011: 379), the result of idealised interpretations of humanism, the Enlightenment, the French Revolution and other 
European 'emancipatory' movements and ideologies (Pasture, 2015). This modernity paradigm has often been projected onto the histories of the non-West (Buzan and Little, 2000) and influences Europe's assumptions, expectations and judgements regarding developmental trajectories in other parts of the world. However, this idea of modernity was 'drawn from very particular intellectual and historical traditions that could not claim any universal validity' (Chakrabarty, 2007: xiii).

A related element of Eurocentrism is the assumption that Europe's current situation is selfevident and that we can look to modern Europe to make judgements about how other countries should behave and develop. As Fukuyama (2011: 14) notes, 'people living in industrialized countries now suffer from a historical amnesia regarding how their societies came to that point in the first place', disregarding the often long, painful and non-linear evolution and the complex historical circumstances under which this occurred, and the diversified reality to which it gave rise. Provincializing thus includes an awareness of evolution and diversity within Europe and the West itself and a willingness to go beyond idealised, mythicised or simplified versions of the own historical trajectories, including the myth of the EU's 'virgin birth', detached from the colonial past of its member states (Bhambra 2016; Nicolaïdis, 2015; Pasture, 2015).

Finally, provincializing entails a consciousness about the particular European perception of time and how this impacts on the analysis of its external relations. As Birth (2016) emphasises, our understanding of temporal diversity is constrained by the logic of European-derived ideas about time. This rather short-term-oriented perspective explains, for example, misperceptions regarding long-term developments in the Islamic world, in peacebuilding processes (Langer and 
Brown, 2016; Reychler, 2015) or in the strategic partnership with China (Stumbaum and Xiong, 2012).

Engagement demands that non-western framings of history also be taken seriously (Tickner and Blaney, 2012: 18-19). Firstly, learning other benchmark dates or foundational events is required, calling for a thorough knowledge of histories and collective memories of other regions and societies, and the implications these may have until this day, including for their perception of and response to EU foreign policy. Historical experiences may be unrelated to western involvement, but can also be associated with imperialism, colonialism, violence and dispossession by Europe and the West. These dynamics are often concealed in European timeframes (Buzan and Lawson, 2014; Pasture, 2015; Shilliam, 2011), but are reflected in benchmark dates in other regions, e.g. commemorations of colonial suppression and independence fights, European conquest and other 'Echoes of Empire' (Nicolaïdis et al., 2015) - all affecting the external perceptions and judgements about current European involvement in other regions. Examples are various western military interventions, the 1916 Sykes-Picot Treaty drawing state borders in the Middle East, or the 'century of humiliation' in China.

Engaging also means paying attention to other perceptions of time and to other developmental trajectories than evolution towards European-style modernity. Not only may modernity have a different starting point elsewhere and are there different trajectories towards it (Delanty and Rumford, 2005; Fisher Onar and Nicolaïdis, 2013). Modernity unavoidably adopts a hybrid character, as people revert to real or 'invented' traditions in shaping their perceptions of what modernity entails (Chakrabarty, 2007; Dirlik, 2003; Hobsbawm and Ranger, 1992). Engagement not merely entails seeing current differences, but also the trial and error of using 
western ideologies in other regions (e.g. nationalism, socialism, liberalism, secularism, capitalism), resulting in a rejection of what did/does not work and a turn to what $\mathrm{did} / \mathrm{does}$. The rise of Islamism constitutes such a hybrid modernity: a multifaceted modern political current with societies, movements and parties in different areas developing variations of this trajectory (Fisher Onar and Müftüler-Baç, 2011; Rubin, 2013). Daesh for example took hybridity to the extreme with its use of 'western' technology and social media on the one hand, but its turn to religion and rejection of state borders drawn by Europe on the other.

Temporal reconstruction in the analysis of European foreign policy towards other regions implies that scholars explicitly take into account local time perspectives and historical experiences. This knowledge can shed light on their effects on the (lack of) local receptivity to EU foreign policy initiatives. For instance, awareness of how people in the Middle East and North Africa (MENA) recall European actions in the region - from the Sykes-Picot Treaty to military interventions in the Suez crisis, Iraq or Libya, or actions against Daesh - can explain the suspicion towards EU demands for more involvement in mediation and peacebuilding initiatives.

\section{Normative decentring}

Finnemore and Sikkink (1998: 891) define a norm as 'a standard of appropriate behaviour for actors with a given identity'. What is deemed acceptable not only changes over time, but also differs according to place (Postel-Vinay, 2008: 39-40), calling into question 'EUniversalism' (Nicolaïdis, 2015: 285) and any other claims to universality of specific normative mind-sets. 
Provincializing allows analysts to become aware of norm prioritisation and the often quite specific interpretation of a norm and its field of application. In the analysis of European foreign policy, the focus generally lies on norms that fit within European and western ideas of a liberal, pluralist order. In the previous section, we already referred to norms deriving from a certain idea of 'Enlightenment' and modernity that have underpinned European truth claims. Within the context of the EU's external relations, the focus is on norms which the EU 'seeks to advance in the wider world: democracy, the rule of law, the universality and indivisibility of human rights and fundamental freedoms, respect for human dignity, the principles of equality and solidarity [...]' (Article 21(1) Treaty on European Union). These norms also permeate the widespread NPE debate (Manners, 2002; Whitman, 2011), although some get much less attention, such as solidarity and dignity. Unpacking European assumptions about norms exposes that these are not necessarily universal, nor of universal priority, although often presented as such. This points to what Tocci (2008: 4) labelled as the 'serious pitfall that has bedevilled much of the literature on EU foreign policy: subjectivity and presumed universality'.

Provincializing also provides deeper insights into how prioritised norms are interpreted and applied. This can be seen in two of the dominant normative narratives in EU foreign policy: human rights and democracy. Provincializing human rights shows that attention for human rights is not only selective, but that 'first generation' civil and political rights are prioritised over 'second generation' economic, social and cultural or 'third generation' solidarity rights. Normative preoccupations also mainly revolve around individual liberties instead of collective rights (cf. infra) (Donnelly, 2007; Moyn, 2010; Zhang, 2012). Provincializing democracy equally shows that European attention for democracy is selective, reflects specific meanings and 
is evaluated within specific parameters (Lamont et al., 2015; Morozov, 2013; Youngs, 2015). For example, democracy is often analysed without taking into account the power of economic actors over democratically elected governments (e.g. influence of capital markets and 'Troika' on the 2015 Greek government).

Engagement requires that analysts learn about prioritised norms in other societies or regions and their specific interpretation and application. Additionally, the question rises how these norms relate to the European normative mind set, if they appear in European thinking at all. In order to allow for comparative analysis and to avoid the aforementioned dangers of knowledge fragmentation and 'othering', it can be analytically useful to position norms on continua of normative thinking, such as responsibilities-rights, individualism-collectivism, secularismreligiosity.

The first continuum is related to variations of the focus on rights and freedoms on the one hand and responsibilities and obligations on the other. Questions that arise are whether the emphasis is on responsibilities or rights (or both), whose responsibilities and rights are emphasised, and towards whom people or entities are responsible. When engaging, we learn that responsibilities towards society may be prioritised over the individual's personal freedom. Examples include obligations towards one's group being seen as morally superior to individual rights in Asian contexts (Zhang, 2012), or the discussion on duties versus rights in Islamic discourses (Orakzai, 2012). This contrasts with the current European/western focus on individual rights, often considered detached from responsibilities or obligations - although this has varied in different stages of Europe's history and still varies throughout European societies. 
Closely related is a second continuum between the individual and collective/relational. Norms can be derived from the intricate interrelation between the individual and the larger social group. Despite major differences between the historical and societal contexts in which these concepts arose, the southern African idea of ubuntu (Smith, 2012), the Russian term lichnost (Kharkhordin, 1999) and the Confusion concept guanxi (Pan, 2016) all reflect notions of relationality: an individual exists within and through a social context. Prioritizing the collective is then considered a fundamentally positive norm. 'Stability' or 'harmony', both in personal relations and in international order, can in this context be of higher priority than e.g. democracy or human rights, which can be considered as problematic if they lead to chaos or do not engender greater equality or social inclusion (Ding, 2012; Morozov, 2013). This focus on relationality also explains the prioritization of values such as 'justice' in the Mediterranean world (al-'adala or 'giving to each his due') (Ayubi, 2005: 18), 'respect' and 'honour', or mianzi or 'face' in Asian contexts.

A third continuum lies between secular and religious/spiritual. Within the context of western secularism and due to the Enlightenment's impact on normative presumptions, religion is a largely ignored category (Sheikh and Wæver, 2012; Wolff, 2015). However, as de Sousa Santos (2002: 48) notes, 'the secular-religious distinction is a distinctly Western one' and may be irrelevant within other normative mind-sets. Within the umma, the personal relationship with Allah is the principal overarching value, implying an array of norms associated with Islamic belief. In Buddhist and Hindu societies, dharma sees the individual primarily as part of a whole and rather than on rights or democracy, the focus lies on 'the primordial imperative, the duty of individuals to find their place in the order of the entire society and of the entire cosmos' (Ibid.: 
49). Both concepts point to a fundamental relationship with a divinity or cosmic order, with implications both for the (ir)relevance of norms promoted by EU foreign policy and how Europe and the West are perceived.

After adopting a more inclusive and comprehensive view on prioritised norms in Europe and in other regions, scholars can examine whether these norms and their relative hierarchy are similar, overlapping, complementary or competing. Normative reconstruction could entail assessments of whether or not the $\mathrm{EU}$ - in its agreements and political dialogues with other regions and $\underline{\text { countries -_pays_attention to norms considered important by external partners, such as 'mutual }}$ respect', 'harmony' or 'stability' in Asian countries. Scholars can investigate how inclusion or exclusion of these norms may explain (mis)understandings in diplomatic settings and successes or failures in attaining European foreign policy objectives.

\section{Polity decentring}

In this section, we employ the term 'polity', conceptualised by Ferguson and Mansbach (1996: 34) as political entities or authority structures that have 'a distinct identity; a capacity to mobilise persons and their resources for political purposes, that is, for value satisfaction; and a degree of institutionalisation and hierarchy (leaders and constituents)'. Underlying polities is an 'exchange phenomenon ${ }^{2}$ in which loyalties and other resources are provided in return for value satisfaction (or relief from value deprivation)' (Ferguson and Mansbach, 1996: 36). Providing the basis for the internal legitimacy of polities, this value satisfaction can be related to the provision of identity, order, security, and other vital public goods and services. It can be

\footnotetext{
${ }^{2}$ Italics by Ferguson and Mansbach (1996).
} 
organised both horizontally (loyalty towards the group and mutual solidarity between its members) and vertically (loyalty and dependency between leading actors and group members) (Keukeleire and Lecocq, forthcoming).

Provincializing polity in the analysis of European foreign policy implies unpacking and questioning a specific set of predominant polities that reflect a Westphalian state-centric and modernity bias (Bartelson et al. forthcoming; Bhambra 2007; Ferguson and Mansbach, 2000; Inayatullah and Blaney, 2004) (see temporal decentring). The state-centric bias means a focus on territorial sovereign states and relations between states (with governments as the most important agents), but also on polities based on states such as international organizations (including partly post-Westphalian polities, such as the EU itself). The modernity bias is reflected in the Weberian conception of the 'modern' state with its institutional and functional capacities and in the dominant western and European focus on individualism, citizenship and the distinctions between public/private, state/society and politics/religion. Taken together, both biases lead to assumptions about the state as the main point of reference as a legitimate authority structure and for providing identity, order, public goods and services.

Unpacking these assumptions requires an awareness of the long and difficult evolution and diversity that was and still is a reality within Europe and the West itself, and the fact that the 'ideal modern state' is more myth than reality. As Ferguson and Mansbach (2003: 25-26, 114) note, two major trends continuously lead to a recession of state influence: on the one hand 'a growth of regional and global networks of authority that link people physically remote from one another [... but effectively] consolidate governance' such as international, regional and nongovernmental organizations, and on the other hand, 'a fracturing of existing territorial states into 
smaller [...] islands of self-identification that localize authority and defy efforts to provide answers to the collective goods dilemma', as is demonstrated by the 'explosion of ethnic, religious, tribal and even "civilizational" self-identities'. This fracturing of existing states is also apparent in the growing number of 'areas of limited statehood' (Risse, 2011; Börzel and Risse, 2016) or supposedly 'ungoverned spaces' (Clunan and Trinkunas, 2010), steered by other types of polities and governance systems. Provincializing thus implies being conscious of what Agnew (1994: 77) calls the 'territorial trap', being the misconception of the 'historical relationship between territorial states and the broader social and economic structures and geopolitical order'.

Engagement requires taking into account and learning about and from a larger set of polities. Apart from states and state-based international and regional organizations, engagement sheds light on various other sub- and transnational authority structures that remain largely invisible in predominant political science frameworks. Within the EU's neighbourhood and in areas of interest to EU foreign policy, polities emerge that are based on i.a. ethnicity, religion, warlordism or combinations thereof. Ethnicity-based polities exist in diverse forms and are labelled $^{3}$ differently in different regions, e.g. tribes and clans in the MENA region or Central Asia (i.a. Salzman, 2015) or ethnic groups, kingdoms or chiefdoms in sub-Sahara Africa (i.a. Chabal and Daloz, 1999; Albrecht, 2018 in this special issue). Religion-based polities are, for example, the broad array of Islamic networks ranging from the wide community of believers or

\footnotetext{
3 Employing terminology related to clans or tribes is often criticised for being closely associated with (neo)colonialism. However, these terms are used by these polities to describe themselves, and leaving the myriad of polities uncategorised leads to the abovementioned pitfalls of neglecting part of reality or being left with merely casespecific knowledge.
} 
umma, to movements such as the Muslim Brotherhood or, in its most radical form, Daesh (i.a. Rubin, 2013; Walby, 2004). Examples of warlordism-based polities are the myriad of warlords, their militias and armed non-state actors in conflict areas in the MENA region, Central Asia and sub-Sahara Africa (i.a. Jackson, 2003; Marten, 2012). These various types of polities can 'overlap, layer, nest, and interact - coexist, cooperate, and conflict in the context of particular issues', reflecting their varying functions and degrees of reach over people, resources, space and issues (Ferguson and Mansbach, 2000: 29-30).

Reconstruction entails that scholars, when assessing European foreign policy regarding e.g. democratisation, good governance or state-building, also gain insight in the existence, nature and effectiveness of other kinds of polities. For example, an in-depth understanding of the Arab uprisings may also require knowledge on 'peripheral' polities, such as tribes and religious groups, instead of focussing merely on established power centres (Huber \& Kamel, 2016). Analysts can examine how these polities - and their ability to provide identity, order, and collective goods and services - relate to structures supported or promoted by European actors. Such comparative analysis can help explain successes and failures of EU foreign policy in third regions and can make both scholars and EU practitioners pay attention to polities in a comprehensive way, beyond judgements about their 'traditional' or 'illegitimate' nature.

\section{Linguistic decentring}

Linguistic decentring is necessary, as 'any language by its structure, its metaphors and its vocabulary imposes a pattern of thought which reflects its parent culture' (Groom, 2005: 169170). Provincializing requires an awareness that the analysis of European foreign policy is 
embedded in and constrained by dominant linguistic frameworks in Europe and the West. A first aspect is the predominance of English in international scholarly debates (see also disciplinary decentring). English as a lingua franca facilitates international academic interaction, but may also inhibit the participation of scholars from other language groups. Related characteristics, as Wæver (1998: 694-695) emphasised, are the dominant stylistic criteria of 'the American brand of the Anglo-Saxon intellectual style, with brief, straightforward statements and linear progression of an argument'. Whereas this can be regarded as spelling out clarity, it may also act as a 'barrier to expressing real complexity' (Wæver, 1998: 694), engendering ‘stylized Manichean representations of complex phenomena' (Fisher Onar and Nicolaïdis, 2013: 288).

Secondly, the majority of European foreign policy analysts rarely use primary and secondary sources in non-European languages such as Arabic, Farsi, Turkmen, Mandarin or Hausa. This implies that potentially relevant literature and data are neglected due to a linguistic barrier and that research on e.g. EU relations with China or the Arab world is often exclusively based on western sources, raising questions about the validity of produced conclusions. Even non-western scholars who convey their research in English often adapt their language to western or European audiences, or represent a distinct socio-economic or political background which is not always representative for their country or society.

Thirdly, European foreign policy analysts may be ignorant of basic concepts, ideas and approaches which are foreign to their own linguistic framework, conceptual lenses and cognitive world, but may be key to understanding other regions and the impact of the European foreign policy towards them. Major differences may also exist in manners of communicating, a 
problem which is not simply solved by translating non-European languages or concepts into society, place and time. Chakrabarty (2007: 17) refers to the problem of 'translating diverse forms, practices, and understandings of life into universalist political-theoretical categories of deeply European origin', leading to “"rough translations" of native terms'.

Linguistic engagement thus implies analysing other regions and societies (and Europe's relations with and foreign policy towards them) from within local linguistic frameworks and contexts. This calls for collaboration with scholars who have sound knowledge of the local language(s) and an understanding of the broader linguistic and communicative context and related conceptual lenses, needed to unveil both fundamental meanings and subtle nuances. Especially the section on normative decentring included examples of meanings getting 'lost in translation' when adopting western terminology for complex non-western concepts (e.g. the meaning of al-adala and lichnost is not covered by 'justice' and 'individual'). Another example is the avoidance of the word 'no' in Asia and the use of indirect strategies to convey a refusal or disagreement vis-à-vis someone else, as these are less 'face-threatening' and in concordance with the basic value of 'harmony' and 'rejection avoidance' (Boonkongsaen, 2013; Hashimoto and Yamagishi, 2013) (see normative decentring).

Through a linguistic reconstruction of EU foreign policy analysis, analysts may, first, reveal gaps in the existing English literature dealing with EU foreign policy by including insights expressed in other languages. Second, with a better understanding of other linguistic frameworks, scholars may reveal differences in the way interests and sensitivities are conveyed as factors influencing the (in)effectiveness of EU foreign policy and public diplomacy. 


\section{Disciplinary decentring}

Disciplinary decentring differs from the previous categories, as it deals with epistemology and methodology and thereby cuts across all other categories. Nevertheless, applying the various decentring dimensions is also useful in this case. To decentre on an epistemological and methodological level implies a consciousness that the analysis of Europe's foreign policy is not only embedded in the research traditions and theoretical perspectives of IR, Political Science, Foreign Policy and EU Studies (Jørgensen 2015a, 2015b), but also constrained by them. Despite their often implicit universal scientific claims, they are rooted in specific European or western contexts, as they are 'the local product of a particular geo-epistemological perspective' (Wæver and Tickner 2009). This also explains why they are often insufficient for understanding issues and challenges faced by other parts of the world, which nevertheless also impact upon Europe and European foreign policy.

Provincializing therefore requires an awareness of the limited receptivity to 'difference' by the predominant research practices and methodological approaches in Political Science, IR and EU Studies. Chabal and Daloz (2006: 12-13) make the important point that the usual a priori definition of a conceptual framework and research questions can be detrimental to seeing difference, as this 'inevitably tends to privilege ethnocentric conceptual frameworks over those that may be argued to be more appropriate for non-Western, or non-industrial societies'. Relevant here is Hudson's (2007: 188) complaint about the continued use of 'inappropriate methods, by employing simplifying assumptions that evade the complexity with which the methods cannot cope'. 
Openness to difference is also hampered by the (explicit or implicit) positivist approach, the prioritization of explanatory research, and the quest for theory-building (Chabal and Daloz, 2006; Thomas and Wilkin, 2006). Although the search for causal relations and explanations may in principle be considered epistemologically preferable to descriptive or exploratory analysis, a major drawback is the resulting tendency to disregard important entities and phenomena which are less easily explained and for which data are more difficult to obtain (see the various examples in the sections on normative decentring and polity decentring). In reference to linguistic decentring, the fact that most research on European foreign policy is mainly or solely based on western primary and secondary sources is also mirrored in the limited number of references to and publications by non-western scholars (Keuleers et al., 2016). What Shilliam (2011) and Tickner (2013) labelled as imperialist core-periphery power relations in IR, may in this sense also be reflected in scholarship on EU foreign policy.

Disciplinary engagement follows rather logically from provincializing, providing remedies to the limitations that came to the fore. On a theoretical level, a first step is incorporating more insights from post-positivist approaches with a larger openness for difference, such as subaltern studies and post-colonial or post-modernization theories - with the caveat that postmodern and postcolonial theorists often 'continue to use Europe as a reference point' (Bhambra 2007: 1). Although a 'non-western IR theory' may not exist (Acharya and Buzan, 2010; Tickner and Wæver, 2009), western scholars can actively seek to learn conceptualizations offered by scholars in the Arab world, Africa, Asia and other areas and engage with different readings of concepts such as democracy, security or sovereignty (see case-studies in Morozov, 2013; Pan, 2012; Tickner and Blaney, 2012), but also with lesser known notions such as guanxi or ubuntu. 
Engaging with non-western scholars and literature can also help European foreign policy specialists to pay attention to a wider set of relevant research problems and questions.

Another step to strengthen engagement is to learn from other academic disciplines and their methodologies, including from how these disciplines evolved and are practiced in other parts of the world. An essential part of this much-needed interdisciplinarity is closer interaction with the already multidisciplinary area studies, which has often been accused of 'epistemological inferiority' (Tickner and Blaney, 2012: 8). This interaction is essential to obtain deeply needed basic information and to gain an understanding of phenomena that are largely unknown to scholars specialised in European foreign policy. Reaching out to local knowledge is thus essential (Kalb, 2006), though not always easy. Standard research guidelines in political science can prove to be of limited use, if only because of the difficulty of obtaining data and using local sources. Methodologies used in disciplines such as anthropology - including field work and (non-)participant observation - can be needed for data collection and for grounding the analysis in the interpretation of what makes sense within local contexts (see the contributions in this special issue - Schröder, 2018). However, this involves a range of specific methodological, ethical, linguistic, financial, logistical and even security challenges, which explains why such disciplinary reconstruction can be very challenging in practice, even when scholars fully acknowledge its necessity (Chabal and Daloz, 2006; Kapiszewski et al., 2015; Olivier de Sardan, 2015).

\section{Concluding remarks: developing the Decentring Agenda}


The analytical framework presented in this article can increase our awareness of both implicit and explicit assumptions in the study of European foreign policy and can enhance our

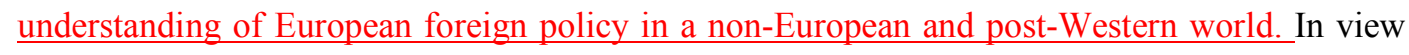
of its complexity and comprehensiveness and the need to explore unknown terrain, researchers will generally not be able to tackle decentring in all its dimensions and categories, except through large interdisciplinary projects. However, interesting and innovative research can be conducted when scholars focus on only one or a few categories and the interactions between them. The framework can support them in developing a wider range of research topics, questions and approaches that can be relevant in the analysis of European foreign policy, other than those that are currently dominating the field.

What are the next steps in this framework's development? First, it serves as a basis for further elaboration, adaptation and sharpening of the various analytical dimensions, (sub)categories and points of attention. Scholars may explore the relevance of additional decentring categories, such as cultural decentring (now partially included in other categories), gender decentring or class decentring (see case-studies in Huber and Kamel, 2016). In addition, they can further refine the 'theoretical case for a research agenda with more attention for outside-in approaches' (Dijkstra and Vanhoonacker, 2017: 281).

Second, scholars can apply the analytical framework on specific case-studies. In turn, these can contribute to developing and refining it, allowing us to judge whether this framework for operationalizing the Decentring Agenda can indeed help 'students of global order - and Europe's place therein - to better grasp the challenges and opportunities of our increasingly 
non-European and post western order' (Fisher Onar and Nicolaïdis, 2013: 296-297) and to better understand how to deal with the multiple crises in the EU's foreign policy (Müller, 2016). And third, as this article focuses mostly on provincializing and engagement, a following step is to further explore how these can be the basis for reconstruction. This can contribute to a renewal of EU external action based on humility, empowerment and mutuality (Fisher Onar and Nicolaïdis, 2013) and to a 'deeper situational awareness' of the EU's actions in an increasingly complex, connected and contested world (EU Global Strategy, 2016: 8, 48).

\section{References}

Acharya A and Buzan B (eds.) (2010) Non-Western International Relations Theory. Perspectives on and beyond Asia. Abingdon: Routledge.

Agnew J (1994) The Territorial Trap: The Geographical Assumptions of International Relations Theory. Review of International Political Economy 1(1): 53-80.

Agnew J (2007) Know-Where: Geographies of Knowledge of World Politics. International Political Sociology 1, 138-148.

Al-Rodhan NRF (2009) Neo-statecraft and Meta-geopolitics. Münster: LIT Verlag.

Bach DC (2011) Patrimonialism and Neopatrimonialism: Comparative Trajectories and Readings. Commonwealth and Comparative Politics 49(3): 275-294.

Bartelson J, Hall M and Teorell J (eds.) (forthcoming) De-Centering State Making: Comparative and International Perspectives. XXX

Bhambra G K (2007) Rethinking Modernity. Postcolonialism and the Sociological Imagination. Basingstoke: Palgrave Macmillan. 
Bhambra G K (ed.) (2016) European Cosmopolitanism: Colonial Histories and Postcolonial Societies. London: Routledge.

Birth K (2016) Time Blind. Problems in Perceiving Other Temporalities. Basingstoke: Palgrave Macmillan.

Bischoff P-H, Aning K and Acharya A (eds) (2016) Africa in Global International Relations. London: Routledge.

Boonkongsaen N (2013) Filipinos and Thais Saying “no" in English. Manusya Journal of Humanities 16(1): $23-40$.

Börzel T A, Dandashly A and Risse T (eds) (2015) Special Issue: Responses to the 'Arabellions': The EU in Comparative Perspective. Journal of European Integration 37(1).

Börzel, T A and Risse T (2016) Dysfunctional state institutions, trust, and governance in areas of limited statehood. Regulation \& Governance 10(2): 149-160

Buzan B and Lawson G (2014) Rethinking Benchmark Dates in International Relations. European Journal of International Relations 20(2): 437-462.

Buzan B and Little R (2000) International Systems in World History. Oxford: Oxford University Press.

Cavatorta F and Pace M (2010) The Post-normative Turn in European Union (EU)-Middle East and North Africa (MENA) Relations: An Introduction. European Foreign Affairs Review 15(5): 581-587.

Chabal P and Daloz J-P (1999) Africa works: disorder as political instrument. Bloomington: Indiana University Press.

Chabal P and Daloz J-P (2006) Culture Troubles: Politics and the Interpretation of Meaning. London: Hurst \& $\mathrm{C}^{\circ}$.

Chaban N and Holland M (2013) Seeing the EU from Outside its Borders, Baltic Journal of European Studies 3(3): 3-14. 
Chakrabarty D (2007) Provincializing Europe. Postcolonial Thought and Historical Difference. Princeton: Princeton University Press.

Chen Z (2016) China, the European Union and the Fragile World Order. Journal of Common Market Studies 54(4): 775-792.

Cole J (2013) A Geography of the European Union. London: Routledge.

Clunan A and Trinkunas HA (2010) Ungoverned Spaces. Stanford: Stanford University Press.

de Sousa Santos B (2002) Towards a Multicultural Conception of Human Rights. In: Hernández-Truyol B (ed.) Moral Imperialism. New York: New York University Press, pp. 39-60.

Delanty G and Rumford C (2005) Rethinking Europe. London: Routledge.

Diez T (2013) Normative power as hegemony. Cooperation and Conflict 48(2): 194-210.

Dijkstra H and Vanhoonacker S (2017) Why study EU foreign policy at all? A response to Keuleers, Fonck and Keukeleire. Cooperation and Conflict 52(2): 280-286.

Ding C (2012) Conceptual Gaps on Stability in Chinese and European Contexts. In: Pan Z (ed.) Conceptual gaps in China-EU Relations. Basingstoke: Palgrave Macmillan, pp. 128-140.

Dirlik A (2003) Global modernity? Modernity in an age of global capitalism. European Journal of Social Theory 6(3): 275-292.

Donnelly J (2007) The Relative Universality of Human Rights. Human Rights Quarterly 29(2): 281-306.

Ejdus F and Juncos AE (eds) (2018) Special Issue: Local perspectives on EU peacebuilding: Effectiveness, ownership and resistance. Contemporary Security Policy.

Erdmann G and Engel U (2007) Neopatrimonialism reconsidered. Commonwealth and Comparative Politics 45(1): 95-119.

EU Global Strategy (2016). Shared vision, common action: a stronger Europe: A global strategy for the European Union's foreign and security policy. Brussels. 
Ferguson YH and Mansbach RW (1996) Polities: Authority, Identities, and Change. Columbia: University of South Carolina Press.

Ferguson YH and Mansbach RW (2000) What is a Polity? A Roundtable. International Studies Review 2(1): 3-31.

Ferguson YH and Mansbach RW (2003) The Elusive Quest Continues: Theory and Global Politics. New Jersey: Pearson Education.

Finnemore M and Sikkink K (1998) International Norm Dynamics and Political Change. International Organization 52(4): 887-917.

Fisher Onar N and Müftüler-Baç M (2011) The Adultery and Headscarf Debates in Turkey: Fusing "EUniversal" and "Alternative" Modernities? Women's Studies International Forum 34(5): 378-389.

Fisher Onar N and Nicolaïdis K (2013) The Decentring Agenda: Europe as a post-colonial power. Cooperation and Conflict 48(2): 283-303.

Fukuyama F (2011) The Origins of Political Order. New York: Farrar, Strauss and Giroux.

Groom J (2005) International Relations in France: a View from Across the Channel. European Political Science 4: 164-74.

Hashimoto H and Yamagishi T (2013) Two Faces of Interdependence: Harmony seeking and rejection avoidance. Asian Journal of Social Psychology 16(2): 142-151.

Hobsbawm E and Ranger T. (eds) (1992) The Invention of Tradition. Cambridge: Cambridge University Press.

Huber D and Kamel L (eds) (2016) Arab Spring and Peripheries. A Decentring Research Agenda. London: Routledge, 2016.

Hudson VM (2007) Foreign Policy Analysis. New York: Rowman \& Littlefield.

Inayatullah N and Blaney DL (2004) International Relations and the Problem of Difference. London: Routledge. 
Jackson P (2003) Warlords as alternative forms of governance. Small Wars and Insurgencies 14(2): 131150.

Jørgensen KE (2010) International Relations Theory. A New Introduction. Basingstoke: Palgrave Macmillan.

Jørgensen KE (2015a) Introduction: Research Traditions. In Jørgensen KE et al. (eds) The SAGE Handbook of European Foreign Policy. London: Sage, pp. 3-13.

Jørgensen KE (2015b) The Study of European Foreign Policy: Trends and Advances. Jørgensen KE et al. (eds), The SAGE Handbook of European Foreign Policy, London: Sage, pp. 14-29.

Jørgensen KE, Aarstad AK, Drieskens E, Laatikainen K. and Tonra B (eds) (2015) The SAGE Handbook of European Foreign Policy. London: Sage.

Kalb D (2006) Uses of Local Knowledge. In: Goodin RE and Tilly C (eds) The Oxford Handbook of Contextual Political Analysis. Oxford: Oxford University Press, pp. 579-594.

Kapiszewski D, MacLean LM and Read BL (2015) Field Research in Political Science. Practices and Principles. Cambridge: Cambridge University Press.

Keukeleire S (2014) Lessons for the Practice and Analysis of EU Diplomacy from an "Outside-In" Perspective. In: Gstöhl S and Lannon E (eds), The Neighbours of the European Union's Neighbours. Surrey: Ashgate, pp. 227-241.

Keukeleire S and Delreux T (2014) The Foreign Policy of the European Union. Basingstoke: Palgrave Macmillan.

Keukeleire S and Lecocq S (forthcoming) Legitimacy and decentring the analysis of EU foreign policy: (re-) introducing "Polity". In Tonra B, Raube K and Sjursen H (eds) Special Issue: Legitimacy and EU Foreign Policy. Global Affairs. 
Keukeleire S and Thépaut C (2012) Towards an Outside-in Approach in the analysis of (European) Foreign Policy. In: The European Union in International Affairs III, Brussels, Belgium, 3-5 May 2012.

Keuleers F, Fonck D and Keukeleire S (2016) Beyond EU Navel-gazing: Taking Stock of EU-centrism in the Analysis of EU Foreign Policy. Cooperation and Conflict 51(3): 1-20.

Kharkhordin O (1999) The Collective and the Individual in Russia. Berkeley: University of California Press.

Lamont CK, van der Harst J and Gaenssmantel F (2015) (eds) Non-Western Encounters with Democratization. Farnham: Ashgate.

Langer A and Brown G. (eds) (2016) Building Sustainable Peace. Timing and Sequencing of PostConflict Reconstruction and Peacebuilding. Oxford: Oxford University Press.

Lucarelli S and Fioramonti L (eds) (2009) External Perceptions of the European Union as a Global Actor. London: Routledge.

Mac Ginty, R., \& Richmond, O. P. (2013). The local turn in peace building: A critical agenda for peace. Third World Quarterly, 34(5), 763-783.

Manners I (2002) Normative Power Europe: a Contradiction in terms? Journal of Common Market Studies 40(2): 235-258.

Marten K (2012) Warlords: Strong-arm Brokers in Weak States. Ithaka: Cornell University Press.

Mayer H and Zielonka J (2012) Europe as a Global Power: View from Outside. Perspectives 20(2): 5129.

Morozov V (ed.) (2013) Decentring the West. The Idea of Democracy and the Struggle for Hegemony. Surrey: Ashgate.

Moyn S (2010) The Last Utopia: Human Rights in History. Cambridge: Harvard University Press. 
Müller P (2016) EU foreign policy: No major breakthrough despite multiple crises. Journal of European Integration 38(3): 359-374.

Nayak M and Selbin E (2010) Decentering International Relations. London: Zed Books.

Nicolaïdis K, Sèbe B and Maas G. (2015) (eds) Echoes of Empire: Memory, Identity and Colonial Legacies. London: Tauris.

Nicolaïdis K (2015) Southern Barbarians? A Post-Colonial Critique of EUniversalism. In Nicolaïdis K et al. (eds) Echoes of Empire. London: Tauris, pp. 283-303.

Olivier de Sardan J-P (2015) Epistemology, Fieldwork and Anthropology. Basingstoke: Palgrave Macmillan.

Orakzai SB (2012) Alternative Discourse on Human Rights. In Bennett S and O’Brien E (eds), What Future for Human Rights in a Non-Western World? London: Human Rights Consortium, pp. 7788.

Pan Z (ed.) (2012) Conceptual Gaps in China-EU Relations, Basingstoke: Palgrave Macmillan.

Pan Z (2016) Guanxi, Weiqi and Chinese Strategic Thinking. Chinese Political Science Review 1(2): 303321.

Pasture P (2015) Imagining European Unity since 1000 AD. Basingstoke: Palgrave Macmillan.

Postel-Vinay K (2008) The Historicity of European Normative Power. In Laïdi Z (ed.) EU Foreign Policy in a Globalized World. London: Routledge, pp. 38-47.

Reychler L (2015) Time For Peace: The Essential Role of Time in Conflict and Peace Processes, Brisbane: University of Queensland Press.

Risse T (ed.) (2011) Governance Without a State? New York: Columbia University Press.

Rubin B (ed.) (2013) Islamic Political and Social Movements. London: Routledge.

Salzman PC (2015) Tribes Today: In Anthropology and in the World. The Journal of the Middle East and Africa 6(3-4): 353-364. 
$\underline{\text { Schröder U (2018) Special Issue: Decentering the Study of International Interventions, Cooperation and }}$ Conflict.

Sheikh MK and Wæver O (2012) Western Secularisms: Variation in a Doctrine and its Practice. In Tickner $\mathrm{AB}$ and Blaney DL (eds), Thinking International Relations Differently. London: Routledge, pp. 275-298.

Shilliam R (ed.) (2011) International Relations and Non-Western Thought, London: Routledge.

Sjursen, H. (2006) The EU as a 'Normative' Power: How Can This Be? Journal of European Public Policy 13(2): 235-251.

Smith K (2012) Contrived Boundaries, Kinship and Ubuntu: a (South) African View on the "International". In: Tickner AB and Blaney DL (eds) Thinking International Relations Differently. London: Routledge, pp. 301-321.

Staeger . (2016) Africa-EU Relations and Normative Power Europe: A Decolonial Pan-African Critique. Journal of Common Market Studies 54(4): 981-998.

Stumbaum M-B and Xiong W (2012) Conceptual Differences of Strategic Partnership in EU-China Relations. In: Pan Z (ed.) Conceptual Gaps in China-EU Relations, Basingstoke: Palgrave Macmillan, pp. 156-172.

Taylor C (2002) Modern Social Imaginaries. Public Culture 14(1): 91-124.

Therborn G (2006) Why and how place matters. In Tilly C and Goodin RE (eds) The Oxford Handbook of Contextual Political Analysis. Oxford: Oxford University Press, pp. 509-533.

Thomas C and Wilkin P (2004) Still Waiting after all these Years: "The Third World" on the Periphery of International Relations. British Journal of Politics and International Relations 6(2): 241-258.

Tickner AB (2003) Seeing IR Differently: Notes from the Third World. Millennium 32(2): 295-324.

Tickner AB (2013) Core, Periphery and (Neo)Imperialist International Relations. European Journal of International Relations 19(3): 627-646. 
Tickner AB and Blaney DL (eds) (2012) Thinking International Relations Differently. London: Routledge.

Tickner AB and Wæver O (eds) (2009) International Relations Scholarship Around the World. London: Routledge.

Tocci N (ed.) (2008) Who is a Normative Policy Actor Brussels: CEPS.

Verloo M (ed.) (2007) Multiple Meanings of Gender Equality. Budapest: CPS Books.

Wæver O (1998) The Sociology of a Not So International Discipline: American and European Developments in International Relations. International Organization 52(4): 687-727.

Wæver O and Tickner AB (2009) Introduction: Geocultural Epistemologies. In: Tickner AB and Wæver O (eds) International Relations Scholarship Around the World, London: Routledge, pp. 1-31.

Walby S (2004) No one Polity Saturates the Political Space in a Given Territory. Sociology 38(5): 10351042.

Whitman RG (2011) (ed.) Normative Power Europe. Basingstoke: Palgrave Macmillan.

Wolff S (2015) US and EU Engagement with Islamists in the Middle East and North Africa. Transatlantic Academy Paper 3.

Youngs R (2015) The Puzzle of Non-Western Democracy. Washington: Carnegie.

Zhang C (2012) The Conceptual Gap on Human Rights in China-Europe Relations. In: Pan Z (ed.) Conceptual Gaps in China-EU Relations. London: Palgrave Macmillan, pp. 83-97. 
Table 1: Operationalizing the Decentring Agenda ${ }^{a}$

\begin{tabular}{|c|c|c|}
\hline DECENTRING & Provincializing & Engagement \\
\hline & $\begin{array}{l}\text { Questioning Eurocentric accounts } \\
\text { and the myth of Eurocentric } \\
\text { civilizational primacy }\end{array}$ & $\begin{array}{l}\text { Learning from the other and } \\
\text { engaging with others' perspectives } \\
\text { and assumptions }\end{array}$ \\
\hline Spatial & $\begin{array}{ll}- & \text { European geographical features } \\
\text { - } & \text { European spatial and material } \\
& \text { situation }\end{array}$ & $\begin{array}{l}\text { - Geographical features of other } \\
\text { spaces } \\
\text { - Other spatial/material contexts }\end{array}$ \\
\hline Temporal & $\begin{array}{ll}\text { - } & \text { European benchmark } \\
\text { dates/events } \\
\text { - } \quad \text { Specific historical trajectory and } \\
\text { modernisation paradigm } \\
\text { - } \quad \text { Specific perception of time }\end{array}$ & $\begin{array}{l}\text { - Other benchmark dates/events } \\
\text { - Other developmental trajectories } \\
\text { and pathways to 'modernity' } \\
\text { (hybridity) } \\
\text { - Other perceptions of time }\end{array}$ \\
\hline Normative & $\begin{array}{l}\text { Pluralist or liberal norms } \\
\text { - } \quad \text { universality? } \\
\text { - } \quad \text { interpretation? } \\
\text { - } \quad \text { application? } \\
\text { - } \quad \text { prioritization/hierarchy? }\end{array}$ & $\begin{array}{l}\text { Other (prioritised) norms: } \\
\text { - } \text { rights and responsibilities } \\
\text { - } \quad \text { individualism and } \\
\text { collectivism/relationality } \\
\text { - } \quad \text { secularism and } \\
\text { religiosity/spirituality }\end{array}$ \\
\hline Polity & - $\quad$ State-centric bias & Different polity types based on: \\
\hline
\end{tabular}


${ }^{a}$ This table combines the provincializing and engagement dimensions as defined by Fisher Onar and Nicolaïdis (2013) with the six decentring categories developed by the authors of this article. 